
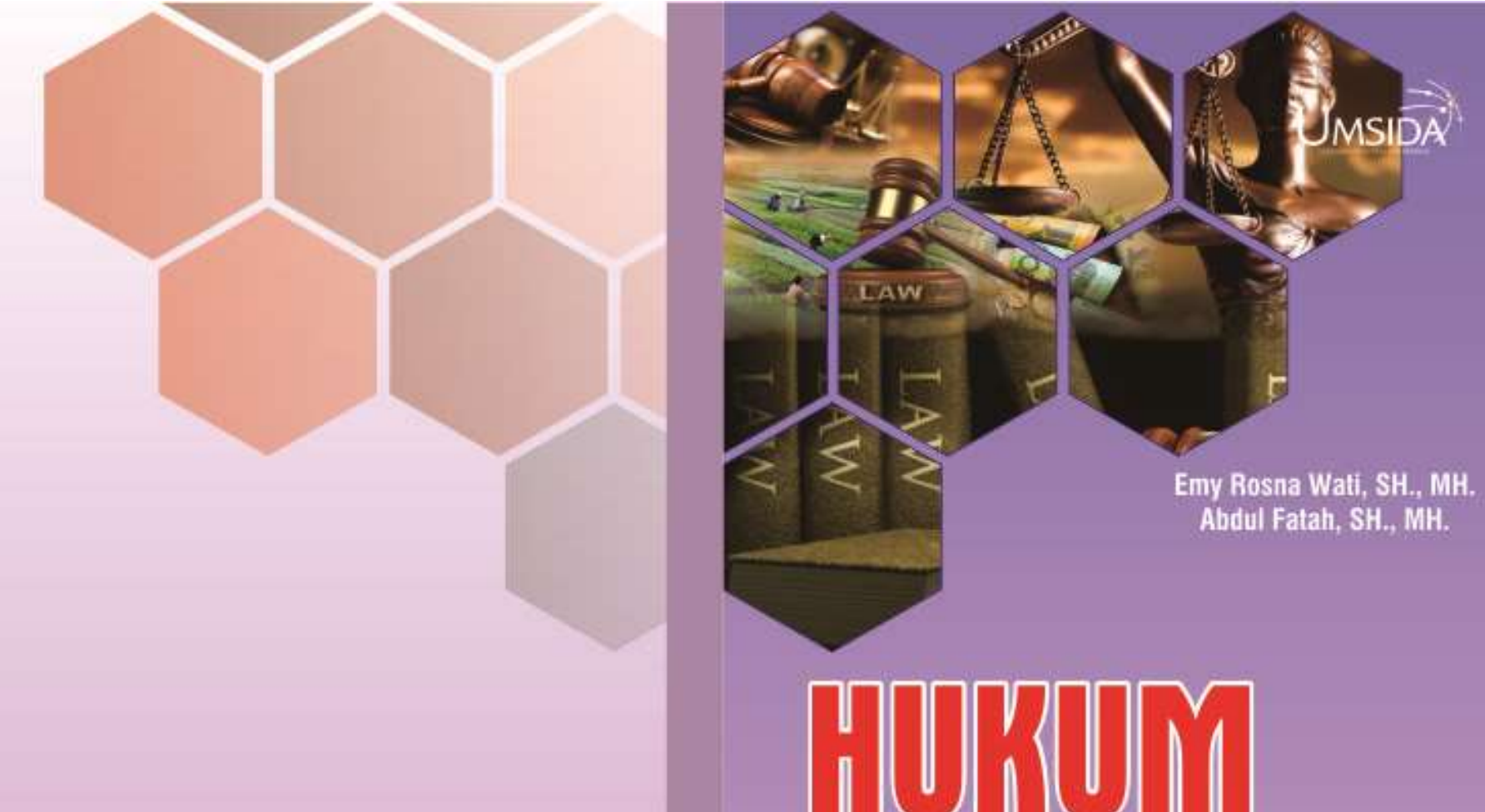

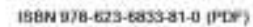
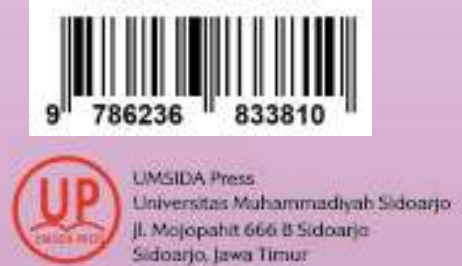


\section{BUKU AJAR \\ HUKUM PIDANA}

Oleh

Emy Rosna Wati, SH., MH.

Abdul Fatah, SH., MH.

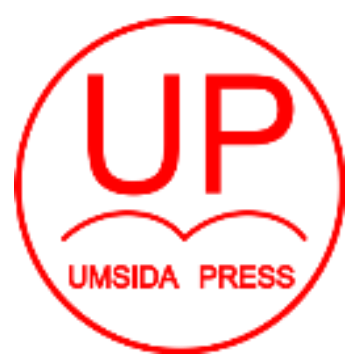

UNIVERSITAS MUHAMMADIYAH SIDOARJO 2020 


\section{BUKU AJAR}

\section{HUKUM PIDANA}

\section{Penulis:}

Emy Rosna Wati, SH., MH.

Abdul Fatah, SH., MH.

\section{ISBN :}

978-623-6833-81-0

\section{Editor:}

Noor Fatimah Mediawati, SH., MH.

\section{Design Sampul dan Tata Letak:}

Mochammad Nashrullah, S.Pd.

Amy Yoga Prajati, S.Kom.

Penerbit:

UMSIDA Press

Anggota IKAPI No. 218/Anggota Luar Biasa/JTI/2019

Anggota APPTI No. 0020181092017

Redaksi

Universitas Muhammadiyah Sidoarjo

Jl. Mojopahit No 666B

Sidoarjo, Jawa Timur

Cetakan Pertama, September 2020

CHak Cipta dilindungi undang undang

Dilarang memperbanyak karya tulis ini dengan sengaja, tanpa ijin tertulis dari penerbit. 


\section{KATA PENGANTAR}

Puji syukur kami panjatkan kehadirat Allah SWT, atas rahmat dan karunia-Nya Buku Ajar Hukum Pidana dapat diselesaikan dengan baik dan tanpa halangan yang berarti. Shalawat dan salam selalu kami sampaikan kepada junjungan Nabi Muhammad SAW.

Tim penulis mengucapkan terimakasih kepada:

1. Wisnu Panggah Setiyono,SE, M.Si Ph.D, Dekan Fakultas Bisnis, Hukum dan IImu Sosial yang memberikan arahan dan motivasi kepada penulis dalam menyelesaikan buku ajar ini.

2. Noor Fatimah Mediawati $\mathrm{SH}, \mathrm{MH}$, Kaprodi Ilmu Hukum yang telah memberikan dukungan untuk menyusun buku ajar ini.

3. Rekan-rekan dosen pengampu Mata Kuliah Hukum Pidana di prodi Ilmu Hukum yang telah berbagi pengalaman dalam mengampu mata kuliah tersebut.

Saran dan kritik sangat penulis harapkan untuk mewujudkan buku ajar Hukum Pidana yang lebih baik dan tentunya sesuai dengan amanat peraturan yang berlaku. Terimakasih.

Tim Penulis 


\section{DAFTAR ISI}

\section{HALAMAN SAMPUL}

KATA PENGANTAR

\section{DAFTAR ISI}

\section{BAB I PERBUATAN PIDANA DAN PEMIDANAAN}

A. Pendahuluan........................................................ 2

B. Pengertian perbuatan pidana.................................... 4

C. Jenis - jenis perbuatan Pidana.................................... 6

D. Unsur - unsur perbuatan pidana.............................. 9

E. Subyek hukum pidana............................................ 9

F. Tujuan Pemidanaan ............................................ 10

\section{BAB II RUANG LINGKUP BERLAKUNYA HUKUM PIDANA}
A. Pendahuluan
B. Ruang Lingkup Berdasarkan waktu
C. Ruang Lingkup berdasarkan tempat

\section{BAB III JENIS - JENIS PIDANA}

A. Pidana Pokok.......................................................... 22

B. Pidana Tambahan ................................................. 23

\section{BAB IV PENYERTAAN}

A. Pengertian Penyertaan........................................ 36

B. Pembuat/daader Tindak Pidana........................... 37

C. Pembantu Tindak Pidana....................................... 40

\section{BAB V GABUNGAN Tindak Pidana}

A. Pengertian Gabungan Tindak Pidana.................... 44

B. Penggabungan Tindak Pidana dalam KUHP........... 45 
C. Jenis - Jenis Gabungan Tindak Pidana.................. 45

D. Syarat - syarat gabungan Tindak Pidana.............. 46

E. Sistem pemidanaan gabungan tindak pidana....... 46

\section{BAB VI PERTANGGUNGJAWABAN PIDANA}

A. Pengertian Pertanggungjawaban Pidana.............. 50

B. Alasan Pemaaf ..................................................... 55

C. Alasan Pembenar ................................................. 58

\section{BAB VII KESENGAJAAN DAN KEALPAAN}
A. Pendahuluan 64
B. Kesengajaan 65
C. Kealpaan 71

\section{BAB VIII PERCOBAAN}
A. Pengertian Percobaan
76
B. Jenis - Jenis Percobaan
80

\section{BAB IX RESIDIVE}
A. Pengertian Residive. 84
B. Jenis - Jenis Residive 85

BAB X GUGURNYA KEWENANGAN MENUNTUT DAN MENJALANKAN PIDANA
A. Gugurnya Kewenangan Menuntut 90
B. Gugurnya Kewenangan Menjalankan Pidana......... 94

\section{BAB XI PENAFSIRAN DALAM HUKUM PIDANA}
A. Pengertian Penafsiran
B. Penafsiran dalam Hukum Pidana 101

\section{BAB XII HUBUNGAN SEBAB AKIBAT TEORI KAUSALITAS}

A. Teori Kausalitas ................................................. 104 
B. Macam - Macam teori Kausalitas............................. .108

C. Kausalitas dalam hal Tidak Berbuat........................ 112

DAFTAR PUSTAKA

BIODATA PENULIS

BATANG TUBUH DAN SUB-CAPAIAN PEMBELAJARAN MATA KULIAH

\begin{tabular}{|c|c|}
\hline BAB & Sub-Capaian Pembelajaran Mata Kuliah \\
\hline $\begin{array}{l}\text { BAB I } \\
\text { PERBUATAN } \\
\text { PIDANA DAN } \\
\text { PEMIDANAAN }\end{array}$ & $\begin{array}{l}\text { 1. Mahasiswa mampu memahami pengertian, jenis dan } \\
\text { unsur perbuatan pidana } \\
\text { 2. Mahasiswa mampu menjelaskan tujuan pemidanaan. }\end{array}$ \\
\hline $\begin{array}{l}\text { BAB II } \\
\text { RUANG } \\
\text { LINGKUP } \\
\text { BERLAKUNYA } \\
\text { HUKUM } \\
\text { PIDANA }\end{array}$ & $\begin{array}{l}\text { 1. Mahasiswa mampu memahami berlakunya hukum } \\
\text { pidana menurut waktu. } \\
\text { 2. Mahasiswa mampu memahami berlakunya hukum } \\
\text { pidana menurut tempat }\end{array}$ \\
\hline $\begin{array}{l}\text { BAB III } \\
\text { JENIS - JENIS } \\
\text { PIDANA }\end{array}$ & $\begin{array}{l}\text { 1. Mahasiswa mampu menjelaskan jenis - jenis pidana } \\
\text { 2. Mahasiswa mampu membandingkan pidana pokok } \\
\text { dan pidana tambahan. }\end{array}$ \\
\hline $\begin{array}{l}\text { BAB IV } \\
\text { PENYERTAAN }\end{array}$ & $\begin{array}{l}\text { 1. Mahasiswa mampu menjelaskan pengertian } \\
\text { penyertaan } \\
\text { 2. Mahasiswa mampu menjelaskan pelaku tindak } \\
\text { pidana dan pembantu tindak pidana }\end{array}$ \\
\hline
\end{tabular}




\begin{tabular}{|c|c|}
\hline $\begin{array}{l}\text { BAB V } \\
\text { GABUNGAN } \\
\text { Tindak Pidana }\end{array}$ & $\begin{array}{l}\text { 1. Mahasiswa mampu menjelaskan pengertian } \\
\text { gabungan Tindak Pidana } \\
\text { 2. Mahasiswa mampu menjelaskan penggabungan } \\
\text { tindak pidana dalam KUHP } \\
\text { 3. Mahasiswa mampu menyebutkan syarat - syarat } \\
\text { gabungan tindak pidana } \\
\text { 4. Mahasiswa mampu menjelaskan sistem pemidanaan } \\
\text { dalam gabungan tindak pidana. }\end{array}$ \\
\hline $\begin{array}{l}\text { BAB VI } \\
\text { PERTANGGUNG } \\
\text { JAWABAN PID } \\
\text { ANA }\end{array}$ & $\begin{array}{l}\text { 1. Mahasiswa mampu menjela skan tentang } \\
\text { pertanggungjawaban Pidana. } \\
\text { 2. Mahasiswa mampu memahami alasan pemaaf } \\
\text { beserta macam-macamnya } \\
\text { 3. Mahasiswa mampu memahami alasan pembenar } \\
\text { beserta macam - macamnya }\end{array}$ \\
\hline $\begin{array}{l}\text { BAB VII } \\
\text { KESENGAJAAN } \\
\text { DAN KEALPAAN }\end{array}$ & $\begin{array}{l}\text { 1. Mahasiswa mampu memahami tentang } \\
\text { kesengajaan beserta macam }- \text { macam } \\
\text { kesengajaan }\end{array}$ \\
\hline $\begin{array}{l}\text { BAB VIII } \\
\text { PERCOBAAN }\end{array}$ & $\begin{array}{l}\text { 1. Mahasiswa mampu menjelaskan pengertian } \\
\text { percobaan. } \\
\text { 2. Mahasiswa mampu menyebutkan jenis - jenis } \\
\text { percobaan } \\
\text { 3. Mahasiswa mampu memahami sanksi pidana } \\
\text { percobaan. }\end{array}$ \\
\hline $\begin{array}{l}\text { BAB IX } \\
\text { RESIDIVE }\end{array}$ & $\begin{array}{l}\text { 1. Mahasiswa mampu memahami tentang residive } \\
\text { 2. Mahasiswa mampu menyebutkan jenis - jenis } \\
\text { residive }\end{array}$ \\
\hline
\end{tabular}




\begin{tabular}{|c|c|}
\hline $\begin{array}{l}\text { BAB X } \\
\text { GUGURNYA } \\
\text { KEWENANGAN } \\
\text { MENUNTUT } \\
\text { DAN } \\
\text { MENJALANKAN } \\
\text { PIDANA }\end{array}$ & $\begin{array}{l}\text { 1. Mahasiswa mampu menyebutkan alasan } \\
\text { gugurnya kewenangan menuntut } \\
\text { 2. Mahasiswa mampu menyebutkan alasan } \\
\text { gugurnya menjalankan pidana }\end{array}$ \\
\hline $\begin{array}{l}\text { BAB XI } \\
\text { PENAFSIRAN } \\
\text { DALAM HUKUM } \\
\text { PIDANA }\end{array}$ & $\begin{array}{l}\text { 1. Mahasiswa mampu menjelaskan tentang } \\
\text { penafsiran dalam hokum pidana. } \\
\text { 2. Mahasiswa mampu menyebutkan macam - } \\
\text { macam penafsiran dalam hukum pidana. }\end{array}$ \\
\hline $\begin{array}{l}\text { BAB XII } \\
\text { HUBUNGAN } \\
\text { SEBAB AKIBAT } \\
\text { TEORI } \\
\text { KAUSALITAS }\end{array}$ & $\begin{array}{l}\text { 1. Mahasiswa mampumenjelaskan teori kausalitas } \\
\text { 2. Mahasiswa mampu menerangkan macam - } \\
\text { macam teori kausalitas } \\
\text { 3. Mahasiswa mampu memahami kausalitas dalam } \\
\text { hal tidak berbuat. }\end{array}$ \\
\hline
\end{tabular}




\section{BAB I}

\section{PERBUATAN PIDANA DAN PEMIDANAAN}

\section{SUB KOMPETENSI}

1. Pendahuluan

2. Pengertian perbuatan pidana

3. Jenis - jenis perbuatan pidana

4. Unsur - unsur perbuatan pidana

5. Subyek hukum pidana

6. Tujuan pemidanaan

\section{TUJUAN PEMBELAJARAN :}

Mahasiswa pada akhir pembelajaran di level kompetensi ini mampu menjelaskan dan memahami pengertian, jenis dan unsur - unsur perbuatan pidana. Kemudian berturut - turut mampu menjelaskan subyek hokum pidana serta mampu menjelaskan tujuan pemidanaan.

\section{INDIKATOR HASIL BELAJAR}

1. Mahasiswa dapat menjelaskan pengertian perbuatan pidana

2. Mahasiswa dapat menjelaskan jenis - jenis perbuatan pidana

3. Mahasiswa dapat menyebutkan subyek hokum pidana

4. Mahasiswa dapat menjelakan unsur - unsur pidana

5. Mahasiswa dapat menjelaskan tujuan pemidanaan.

\section{MATERI}

\section{A. Pendahuluan}

Satu kebutuhan pokok dalam kajian hukum pidana sebelum masuk pada bahasan perbuatan pidana dan pemidanaan, kiranya perlu untuk memahami hukum pidana itu sendiri terlebih dahulu. 
Hukum pidana menurut Hazewinkel Suringa terkandung tiga rumusan sebagai berikut: ${ }^{1}$

a.Perintah dan larangan, yang atas pelanggarannya telah ditentukan ancaman sanksi terlebih dahulu dan telah ditetapkan oleh lembaga Negara yang berwenang.

b Aturan-aturan yang menentukan bagaimana atau dengan alat apa negara dapat memberikan reaksi pada mereka yang melanggar aturan-aturan tersebut. C. Kaidah-kaidah yang menentukan ruang lingkup berlakunya peraturan-peraturan tersebut pada waktu tertentu dan di wilayah Negara tertentu.

Sedangkan Moeljatno memberikan rumusan berbeda, hukum pidana memberikan dasar dan aturan-aturan untuk hal-hal sebagai berikut : ${ }^{2}$

a. Menentukan perbuatan-perbuatan mana yang tidak boleh dilakukan, yang dilarang dengan disertai ancaman atau sanksi berupa pidana tertentu, bagi barang siapa melanggar larangan tersebut.

b. Menentukan kapan dan dalam hal-hal apa, kepada mereka yang telah melanggar larangan itu dapat dikenakan atau dijatuhi pidana sebagaimana yang telah diancamkan.

c. Menentukan dengan cara bagaimana pengenaan pidana itu dapat dilaksanakan apabila ada orang yang disangka telah melanggar larangan tersebut.

\footnotetext{
1 Andi Zaenal Abidin, Asas-asas Hukum Pidana Bagian Pertama, Alumni, Bandung, 1987, hal 1

2 Moeljatno, Asas-asas Hukum Pidana, Gajah Mada University Press, Yogyakarta, 1980, hal. 1
} 
Jenis hukum pidana ada dua yaitu hukum pidana umum dan hukum pidana khusus. Pidana umum adalah hukum pidana yang berlaku untuk setiap orang, yang sumbernya ada di KUHP yang terdiri atas :

- Buku I tentang Ketentuan Umum (Pasal 1 - Pasal 103).

- Buku II tentang Kejahatan (Pasal 104 - Pasal 448).

- Buku III tentang Pelanggaran (Pasal 449-569).

Hukum pidana khusus (bijzonder starfrecht) adalah aturanaturan hukum pidana di luar dari hukum pidana umum. Misalnya hukum pidana militer, hukum pidana fiskal (pajak), hukum pidana ekonomi, pidana politik, dan lain sebagainya.

Hukum pidana adalah hukum publik, sehingga sifat hukum pidana adalah hukum publik. Sumber hukum pidana adalah KUHP, UU di luar KUHP dan hukum adat.

Fungsi hukum pidana sebagaimana pendapat HLA Hart adalah melindungi masyarakat terhadap kejahatan yang diakibatkan oleh setiap pelanggaran undang-undang. Sedangkan menurut Wilkins, hukum pidana adalah memperkecil kemungkinan pelaku kejahatan mengulangi perbuatannya. ${ }^{3}$

Hukum pidana memiliki relasi yang erat dengan ilmu hukum pidana. Ilmu hukum pidana sendiri adalah ilmu pengetahuan normatif yang mengkaji hukum pidana positif, termasuk sanksi dan asas-asas hukumnya. Ilmu hukum pidana menganalisis,

${ }^{3}$ Bemmelen, Hukum Pidana I, Binacipta, Jakarta, 1984, hal. 37 
menyusun secara sistematis aturan-aturan tersebut, mencari asasasas yang menjadi dasar dari peraturan perundang-undangan yang berlaku dan memberikan penilaian terhadap asas-asas tersebut.

\section{B. Pengertian Perbuatan Pidana}

Istilah perbuatan pidana dalam pemikiran hukum Indonesia adalah bukan istilah tunggal. Istilah perbuatan pidana merupakan padanan dari istilah tindak pidana dan peristiwa pidana. Istilahistilah ini merupakan terjemahan dari bahasa Belanda Strafbaar feit. Hukum pidana dalam perkembangannya diterjemahkan menjadi berbagai istilah :

1. Tindak Pidana

Istilah tindak pidana dipergunakan dalam peraturan perundang

- undangan dimasa sekarang. Pertama kali undang - undang yang menggunakan istilah ini adalah Undang - Undang Darurat nomor 7 tahun 1955. Satochid Kartanegara menggunakan menggunakan istilah tindak pidana dengan alasan memberikan pengertian berbuat atau melakukan (Active Handeling) dan tidak melakukan atau berbuat (Passive Handeling.$^{4}$ Istilah ini juga dipergunakan oleh Wirjono Prodjodikoro ${ }^{5}$, Sianturi ${ }^{6}$ dan Sudarto. ${ }^{7}$

\footnotetext{
${ }^{4} \mathrm{Sr}$. Sianturi, Asas-asas Hukum Pidana di Indonesia dan Penerapannya, Alumni AHAEM-PETAHAEM, Jakarta, 1989. Hal. 208

5 Wirjono Prodjodikoro, Asas-asas Hukum Pidana di Indonesia, PT. Eresco, JakartaBandung, 1981, hal. 50

${ }^{6}$ SR. Sianturi, Loc. Cit

7 Sudarto, Hukum Pidana Jilid 1A, Bagian Penerbitan dan Biro Perpustakaan dan Penerbitan, Fakultas Hukum dan Pengetahuan Masyarakat Universitas Brawijaya, Malang, 1974 hal 42.
} 
2. Peristiwa Pidana, istilah yang dipakai dalam Undang-Undang Dasar Sementera (UUD 1950). Istilah ini juga dipergunakan oleh Ernest Utrect. ${ }^{8}$

3. Perbuatan yang dapat dihukum, istilah ini dipergunakan dalam Undang-Undang Darurat No. 2 Tahun 1951.

4. Perbuatan Pidana, istilah yang dipergunakan dalam UndangUndang Darurat (drt) No. 1 Tahun 1951. Istilah ini dipergunakan oleh Roeslan Saleh dan Muljatno. Menurut mereka perbuatan pidana adalah keadaan yang dibuat oleh seseorang. Perbuatan pidana adalah perbuatan yang dilarang oleh suatu aturan hukum, larangan mana disertai dengan ancaman (sanksi) yang berupa pidana tertentu, bagi yang melanggar larangan tersebut. Larangan ditujukan pada perbuatan (suatu keadaan atau kejadian yang ditimbulkan oleh kelakuan orang), sedangkan ancaman pidananya ditujukan pada orang yang melakukan perbuatan tersebut. ${ }^{9}$

5. Pelanggaran Pidana

Tirtoamidjoyo mempergunakan istilah pelanggaran pidana dalam bukunya yang berjudul Pokok - Pokok Hukum Pidana yang diterbitkan tahun 1955

\footnotetext{
8 Utrecht, Hukum Pidana 1 Pustaka Tirta Mas, Surabaya, 1994 hal, 251.

9 Muljatno, Azas-azas Hukum Pidana, Bina Aksara, Jakarta, 1983 hal. 54.
} 
6. Delik, istilah yang dipergunakan oleh Andi Hamzah, ${ }^{10}$ Oemar Senoadji dan Andi Zainal Abidin. Andi Zainal Abidin dalam bukunya Asas-asas Hukum Pidana Bagian Pertama, mengatakan istilah delik berasal dari bahasa latin "delictum, delicta". Alasannya menggunakan istilah delik, karena istilah itu singka, bersifat universal, dan dapat memenuhi keperluan pemidanaan badan, badan hukum, organisasi, sesuai dengan perkembangan hukum pidana di seluruh dunia. ${ }^{11}$

\section{Jenis - Jenis Perbuatan Pidana}

Jenis perbuatan pidana (delik) dibedakan menjadi sepuluh kategori yaitu :

1. Perbuatan pidana kejahatan dan perbuatan pidana pelanggaran (Buku II dengan Buku III KUHP). Kejahatan adalah perbuatan pidana yang dirumuskan dalam Buku II KUHP, sedangkan pelanggaran dirumuskan dalam Buku III KUHP. Kejahatan seringkali disebut dengan rechtdelicten, sedangkan pelanggaran disebut dengan wet delicten.

2. Perbuatan pidana formil dan perbuatan pidana materiil. Perbuatan pidana formil adalah perbuatan pidana yang penekannya pada dilarangnya suatu perbuatan, contohnya Pasal 160, 209, 210, 242, 263, 362 KUHP. Sedangkan perbuatan pidana materiil adalah perbuatan pidana yang penekannya pada dilarangnya akibat contoh Pasal 187, 378, 338 KUHP.

\footnotetext{
10 Andi Hamzah, Asas-asas Hukum Pidana di Indonesia dan perkembangannya, sofmedia, Jakarta, 2012 hal. 118

11 Andi Zainal Abidin, Asas-asas Hukum Pidana Bagian Pertama, Alumni, Bandung, 1987 hal 246.
} 
3. Perbuatan pidana commisionis, delik ommisionis dan perbuatan pidana commisionis per ommisionem commissa.

a. Perbuatan pidana commissionis

Adalah perbuatan pidana yang berupa pelanggaran terhadap larangan, ialah berbuat sesuatu yang dilarang. Misalnya pencurian, penggelapan,penipuan.

b. Perbuatan pidana ommissionis

Adalah pelanggaran terhadap perintah yaitu tidak melakukan apa yang diperintahkn oleh undang - undang . misalnya pasal 522 (tidak menghadap sebagai saksi dipengadilan), pasal 531 (tidak menolong orang yang memerlukan pertolongan.

c. Perbuatan pidana comissionis per ommissionem commissa

Perbuatan pidana yang berupa pelanggaran terhadap larangan (commissionis) akan tetapi dilakukan dengan cara tidak berbuat (ommissionis). Misalnya seorang ibu yang membunuh anaknya dengan tidak memberi air susu.

4. Perbuatan pidana dolus dan perbuatan pidana culpa. Perbuatan pidana dolus adalah perbuatan yang mengandung unsur kesengajaan, contohnya Pasal 187, 245, 310 KUHP. Sedangkan perbuatan pidana culpa adalah perbuatan yang mengandung unsur kealpaan contohnya Pasal 197, 201, 203 KUHP. 
5. Perbuatan pidana tunggal dan perbuatan pidana ganda. Perbuatan pidana tunggal yaitu perbuatan pidana seputar perbuatan yang dilakukan satu kali saja. Sedangkan perbuatan pidana ganda adalah perbuatan yang baru menjadi perbuatan pidana apabila dilakukan berulang misalnya Pasal 481 KUHP.

6. Perbuatan pidana selesai (rampung) dan perbuatan pidana yang berlanjut terus (berlanjut).

7. Perbuatan pidana aduan dan perbuatan pidana biasa. Perbuatan pidana aduan adalah yang penuntutannya didasari oleh adanya pengaduan dari pihak korban. Perbuatan pidana aduan ada dua jenis perbuatan pidana aduan absolute dan perbuatan pidana aduan relatif. Perbuatan pidana biasa adalah delik yang kewenangan penuntutannya berapa pada penuntut umum. Penuntut umum atas nama Negara demi kepentingan masyarakat.

8. Perbuatan pidana sederhana dan perbuatan pidana yang terkualifikasi. Perbuatan pidana sederhana misalnya Pasal 351 dan 362 KUHP. Sedangkan perbuatan pidana yang terkualifikasi biasanya ada pemberatan, contohnya pencurian dengan pemberatan..

9. Perbuatan pidana umum dan perbuatan pidana propria. Perbuatan pidana umum adalah perbuatan pidana yang dapat dilakukan oleh siapapun, sedangkan perbuatan pidana propria yang hanya dapat dilakukan oleh orang-orang tertentu biasanya terkait jabatan. 
10. Perbuatan pidana kejahatan umum dan kejahatan politik.

D. Unsur - Unsur Perbuatan Pidana

Menurut Simons bahwa unsur perbuatan pidana adalah perbuatan yang dilakukan oleh manusia, bersifat melawan hukum, diancam dengan pidana, dilakukan oleh orang mampu bertanggungjawab. Menurut Simons ini ada dua unsur, yaitu unsur obyektif dan subyektif. ${ }^{12}$ Sedangkan menurut Pompe unsur perbuatan pidana terdiri atas perbuatan yang bersifat melawan hukum, dilakukan dengan kesalahan dan diancam dengan pidana. ${ }^{13}$

\section{E. Subyek Hukum}

Hampir setiap rumusan pasal dalam undang - undang diawali dengan kata "Barangsiapa".Kata barangsiapa berarti orang. Dan dalam delik tertentu subyek tindak pidana adalah badan hukum (konsep korporasi).

\section{F. Tujuan Pemidanaan}

Pemidanaan secara garis besar ada beberapa teori yang dipergunakan. Teori-teori tersebut adalah :

12 Simons, 1992, Kitab Pelajaran Hukum Pidana (Leerboek Van Het Nederlanches Strafrecht), terjemahan dari PAF Lamintang, Bandung,, Pionir Jaya, Bandung, hal 125127.

13 Sudarto, Op. Cit, hal 46. 
1. Teori Absolut (vergeldingstheorien), teori ini dikenal dengan konsep pembalasan. Menurut teori ini hukuman dijatuhkan sebagai pembalasan terhadap pelaku tindak pidana.

2. Teori Relatif (Doeltheorien), teori ini menghendaki pemidanaan ada untuk menciptkan ketertiban di dalam masyarakat (public order).

3. Teori gabungan, menggubungkan dua teori sebelumnya.

4. Dalam konsep pembaharuan hukum pidana, pemidanaan bertujuan :

a. Mencegah dilakukannya tindak pidana dengan menegakan norma hukum demi pengayoman masyarakat. b.

Memasyaratkan terpidana dengan mengadakan permbinaan sehingga menjadi orang yang baik dan berguna. c. Menyelesaikan konflik yang ditimbulkan oleh tindak pidana, memulihkan keseimbangan, dan mendatangkan rasa damai dalam masyarakat. d. Membebaskan rasa bersalah pada terpidana

\section{SOAL - SOAL LATIHAN}

1. Jelaskan pengertian perbuatan pidana

2. Jelaskan jenis - jenis perbuatan pidana

3. Sebutkan subyek hokum pidana

4. Jelaskan yang dimaksud dengan unsur - unsur pidana.

5. Jelskan tujuan pemidanaan.

\section{REFERENSI}


Andi Zaenal Abidin, 1997 Asas-asas Hukum Pidana Bagian Pertama, Bandung, Alumni,

Andi Hamzah, 2012, Asas-asas Hukum Pidana di Indonesia dan perkembangannya, Jakarta, sofmedia,

Bemmelen, 1984, Hukum Pidana I, Jakarta, Binacipta,

Moeljatno, 1980, Asas-asas Hukum Pidana, Yogyakarta, Gajah Mada University Press,

Moeljatno, 1983, Azas-azas Hukum Pidana, Jakarta, Bina Aksara,

Sudarto, 1974, Hukum Pidana Jilid 1A, Malang, Bagian Penerbitan dan Biro Perpustakaan dan Penerbitan, Fakultas Hukum dan Pengetahuan Masyarakat Universitas Brawijaya,

SR Sianturi, 1989, Asas-asas Hukum Pidana di Indonesia dan Penerapannya, Jakarta, Alumni AHAEM-PETAHAEM,

Simons, 1992, Kitab Pelajaran Hukum Pidana (Leerboek Van Het Nederlanches Strafrecht), terjemahan dari PAF Lamintang, Bandung ,Pionir Jaya,

Projodikoro wiryono,1986, Asas-asas Hukum Pidana Indonesia, Bandung, PT. Eresko, 


\section{SUB KOMPETENSI}

1. Pendahuluan

2. Ruang lingkup berdasarkan waktu

3. Ruang lingkup berdasarkan tempat

\section{TUJUAN PEMBELAJARAN}

Mahasiswa mampu memahami ruang lingkup berlakunya hukum pidana menurut tempat dan waktu.

\section{INDIKATOR HASIL BELAJAR}

1. Mahasiswa dapat menjelaskan secara detail ruang lingkup berlakunya hukum pidana berdasarkan waktu

2. Mahasiswa dapat menjelaskan secara detail ruang lingkup berlakunya hukum pidana berdasarkan tempat.

\section{MATERI}

\section{A Pendahuluan}

Hukum pidana dipergunakan untuk mengatur ketertiban di dalam masyarakat. Pemberlakukan hukum pidana dibatasi oleh dua hal yang penting, yaitu batas waktu (diatur dalam Buku I Bab 1 Pasal 1 KUHP) dan batas tempat dan orang (diatur dalam Buku I Bab1 Pasal 2-9 KUHP).

\section{B Ruang Lingkup Berdasarkan Waktu}

Berlakunya hukum pidana didasarkan pada batasan waktu. Perbuatan dinyatakan perbuatan pidana apabila dilakukan pada waktu tertentu setelah peraturan hukum mengaturnya. Hal ini diatur dalam Pasal 1 ayat (1) KUHP. 
(1) Tiada suatu perbuatan dapat dipidana kecuali berdasarkan kekuatan ketentuan perundang - undangan pidana yang telah ada sebelumnya.

(2) Jika ada perubahan dalam perundang - undangan sesudah perbuatan dilakukan, maka terhadap terdakwa diterapkan ketentuan yang paling menguntungkan.

Di dalam Pasal 1 ayat (1) KUHP terkandung asas hukum pidana legalitas. Dalam bahasa latin disebut "nullum delictum, nulla puna sine praevia legi punali" (tiada kejahatan, tiada hukum pidana tanpa undang-undang hukum pidana dahulu). Dalam asas ini ada tiga pengertian :

a. Aturan hukum pidana harus bersumber dari peraturan tertulis (Nulla Poena Sine Lege);

b. Aturan hukum pidana tidak boleh ditafsirkan secara anologis (Nulla Poena Sine Crime);

c. Aturan hukum pidana tidak boleh berlaku surut (retro aktif) (Nulla Crimen Sine Poena Lege).

Moeljatno memberikan rumusan terdapat tiga hal yang terkandung dalam asas legalitas, yaitu: ${ }^{14}$

a. Suatu perbuatan tidak boleh diancam pidana jika perbuatan tersebut belum diatur terlebih dahulu dalam undang - undang atau peraturan. Dengan kata lain peraturan harus ada terlebih dahulu.

${ }^{14}$ Moeljatno, Op. Cit, hal 25. 
b. Untuk menentukan adanya perbuatan pidana tidak boleh digunakan analogi. Analogi terjadi apabila suatu peraturan hokum menyebut dengan tegas suatu kejadian tetapi peraturan tersebut ipergunakan juga bagi kejadian/peristia lain yang tidak termasuk dalam peratran itu, karena banyak persamaannya dengan kejadian yang disebut tadi.

Contoh :

ketentuan pasal 365 (2) sub 1 KUHP melarang melakukan pencurian dalam kereta api atau trem yang sedang berjalan. Jika terjadi pencurian dalam bis maka tidak diberlakukan ketentuan pasal 365 (2) sub 1 KUHP

c. Aturan-aturan hukum pidana tidak berlaku surut.

Tiada perbuatan pidana tanpa undang - undang pidana terlebih dahulu . Ketentuan hukum pidana boleh berlaku surut apabila :

a. Harus ada perubahan perundang - undangan mengenai suatu perbuatan

b. Perubahan tersebut terjadi setelah perbuatan dilakukan.

c. Dimana peraturan baru lebih menguntungkan bagi pelaku perbuatan tersebut.

Dari pengertian dasar diatas tampak benar bahwa asas legalitas ini berlatar belakang kepastian hukum yang berkaitan dengan perlindungan yang lebih konkrit terhadap hak - hak warga negara yang berhadapan dengan kekuasaan pemerintah negara. Dengan asas legalitas terhindar dan 
mencegah kesewenang - wenangan penguasa dalam bidang peradilan pidana. Asas legalitas adalah kepastian hukum.

\section{Ruang Lingkup Berdasarkan Tempat}

Berlakunya hukum pidana selain didasarkan pada batasan waktu juga didasarkan pada tempat sebagaimana ketentuan Pasal 2-9 KUHP. Hal ini dikenal dengan istilah locus delicti.

1. Pengertian locus delicti. Locus delicti adalah tempat terjadinya suatu tindak pidana atau lokasi tempat kejadian perkara atas sutau tindak pidana terjadi. Istilah lain dari locus delicti adalah yurisdiksi.

2. Teori locus delicti.

Locus delicti diperlukan karena berhubungan dengan Pasal 29 KUHP . Locus delictie adalah tempat seseorang melakukan suatu tindak pidana. Dengan diketahuinya tempat tindak pidana dilakukan maka dapat ditentukan pengadilan mana yang mempunyai wewenang untuk mengadili pelaku tindak pidana. Selain itu

3. asas berlakunya locus delicti

Pasal 2- 9 KUHP mengatur ada empat asas yang dipergunakan yaitu :

a. asas teritorial,

b. asas personal (asas nasional aktif),

c. asas perlindungan (asas nasional pasif)

d. asas universal. 


\section{Ad.1 Asas teritorial}

Asas territorial disebutkan :

"Ketentuan pidana dalam perundang - undangan Indonesia diterapkan bagi setiap orang yang melakukan suatu tindak pidana di Indonesia".

Asas territorial lebih menitikberatkan tempat terjadinya .suatu tindak pidana dalam wilayah negara.asas territorial tidak menghiraukan siapa pelakunya. Apakah pelaku warganegara Indonesia atau warga Negara asing. Perluasan asas territorial yang menyebutkan :

"ketentuan pidana dalam perundang - undangan Indonesia berlaku bagi setiap orang yang diluar wilayah Indonesia melakukan tindak pidana didalam kendaraan air atau pesawat udara Indonesia"

Pasal diatas bertujuan agar tindak pidana yang terjadi baik diatas kapal laut yang berada diperairan bebas maupun diatas pesawat terbang yang berada diatas udara bebas ada yang mengadili.

Asas - asas ekstra territorial/kekebalan dan hak-hak istimewa

- Kepala negara asing dan anggota keluarganya

- Pejabat - pejabat perwakilan asing dan keluarganya

- Pejabat - pejabat pemerintahan negara asing yang berstatus diplomati yang dalam perjalanan melalui negara - negara lain atau menuju negara lain. 
- Suatu Angkatan bersenjata yang terpimpin

- Pejabat - pejabat badan internasional

- Kapal - kapal perang dan pesawat udara militer/ABK diatas kapal maupun diluar kapal.

Ad 2. Asas personal

Asas personal diatur dalam pasal 5 KUHP yaitu hukumpidana Indonesia berlaku bagi warga negara Indonesia yang melakukan perbuatan pidana tertentu, kejahatan terhadap keamanan negara, martabat kepala negara, penghasutan dan lain - lain.

Asas personal ini tidak semua pasal diterapkan namun hanya pasal tertentu yang dirasa penting untuk melindungi kepentingan nasional. Asas personal diberlakukan bagi setiap warga Negara yang telah melakukan tindak pidana diluar wilayah territorial Negara.

Asas personal bertujuan untuk mencegah warga Negara asing yang telah melakukan tindak pidana diluar wilayah Indonesia dengan jalan melakukan naturalisasi (menjadi warga Negara Indonesia)

Ad. 3 Asas Perlindungan

Asas perlindungan tercantum dalam pasal 4 KUHP. Asas perlindungan sebagaimana tercantum dalam pasal 4 KUHP bertujuan untuk melindungi kepentingan suatu Negara maupun kepentingan universal ( Internasional) Dikatakan melindungi kepentingan nasional karena pasal 4 KUHP ini memberlakukan perundang - undangan pidana indonesia bagi setiap orang yang 
diluar wilayah negara Indonesia memberlakukan perbuatan perbuatan yang merugikan kepentingan nasional yaitu :

1) Kejahatan terhadap keamanan negara dan kejahatan terhadap martabat/kehormatan presiden republic Indonesia dan wakil presiden republic Indonesia (pasal 4 ke 1). 2) Kejahatan mengenai pemalsuan mata uang atau uang kertas Indonesia atau segel/materai dan merek yang digunakan oleh pemerintah Indonesia (pasal 4 ke-2). $\quad 3$ ) Kejahatan mengenai pemalsuan surat - surat hutang atau sertifikat sertifikat hutang yang dikeluarkan oleh negara Indonesia atau bagian - bagiannya (pasal 4 ke -3)

4). Kejahatan mengenai pembajakan kapal laut Indonesia dan pembajakan pesawat udara Indonesia (pasal 4 ke-4)

Ad 4. Asas Universal

Asas universal bertujuan untuk melindungi kepentingan universal (internasional). Asas ini didasari pemikiran bahwa semua negara wajib mematuhi tata hukum internasional.

\section{SOAL - SOAL LATIHAN}

1. Jelaskan secara lengkap ruang lingkup hukum pidana berdasarkan waktu

2. Jelaskan secara lengkap ruang lingkup berlakunya hukum pidana menurut tempat.

\section{REFERENSI}


Moeljatno, 1980, Asas-asas Hukum Pidana, Yogyakarta, Gajah Mada University Press,

\section{BAB III \\ JENIS - JENIS PIDANA}

\section{SUB KOMPETENSI}

1. Pidana Pokok

2. Pidana Tambahan 


\section{TUJUAN PEMBELAJARAN}

Mahasiswa pada akhir pembelajaran di level kompetensi ini mampu memahami jenis - jenis pidana yang ada di Indonesia dan mampu membandingkan antara pidana pokok dan pidana tambahan.

\section{INDIKATOR HASIL BELAJAR}

1. Mahasiswa dapat menyebutkan dan menjelaskan secara rinci tentang jenis - jenis pidana

2. Mahasiswa dapat menguraikan secara rinci perbedaan antara pidana pokok dan pidana tambahan.

\section{MATERI}

Secara norma jenis pidana diatur dalam Pasal 10 sampai 43 KUHP. Hukum pidana membagi jenis pidana menjadi dua jenis yaitu pidana pokok dan pidana tambahan.

\section{A. Pidana Pokok}

Pidana pokok terdiri atas :

1. Pidana mati,

2. Pidana penjara,

3. Pidana kurungan,

4. Pidana denda dan

5. Pidana tutupan.

\section{B. Pidana Tambahan}

1. Pencabutan hak - hak tertentu

2. Perampasan barang - barang tertentu

3. Pengumuman putusan hakim 
Perbedaan Antara pidana pokok dan pidana tambahan :

1. Penjatuhan salah satu jenis pidana pokok bersifat keharusan (imperative) sedangkan penjatuhan pidana tambahan bersifat facultative. Penjatuhan pidana bersifat keharusan berarti apabila seseorang terbukti bersalah secara sah dan meyakinkan maka hakim harus menjatuhkan satu jenis pidana pokok sesuai dengan jenis dan batas maksimum khusus yang diancamkan pada tindak pidana yang bersangkutan.

2. Penjatuhan jenis pidana pokok tidak harus bersamaan dengan menjatuhkan pidana tambahan ( berdiri sendiri) sedangkan penjatuhan pidana tambahan tidak diperbolehkan tanpa dengan menjatuhkan pidana pokok.

\section{Ad. 1 Pidana Mati (death penalty)}

Pidana mati atau capital punishment, dari bahasa latin "coput". Pidana mati dipahami sebagai hukuman yang dijalankan dengan membunuh atau menghilangkan nyawa orang yang bersalah. Pidana ini jenis pidana yang paling berat.

Pengertian hukuman mati merupakan salah satu bentuk sanksi pidana yang mengandung keseluruhan ketentuan dan larangan sekaligus memaksa si terhukum (pelaku). ${ }^{15}$ Tujuan dari hukuman mati ini adalah pembalasan yang lebih menonjol. Pidana mati merupakan ancaman maksimal terhadap suatu tindak pidana yang telah diatur secara normatif dalam Pasal 10 KUHP sebagai bentuk pidana pokok dan telah dilaksanakan di Indonesia. Di dalam

\footnotetext{
${ }^{15}$ Bambang Waluyo, Pidana dan Pemidanaan, Sinar Grafika, Jakarta, 2008 hal. 10.
} 
KUHP ada Sembilan tindak pidana yang dapat dihukum dengan hukuman mati, yaitu :

a. Makar dengan maksud membunuh presiden dan wakil presiden (Pasal 104 KUHP)

b. Melakukan hubungan dengan Negara asing sehingga terjadi perang (Pasal 111 ayat (2) KUHP)

c. Pengkianatan memberitahukan kepada musuh di waktu perang (Pasal 124 ayat (3) KUHP)

d. Menghasut dan memudahkan terjadinya huru-hara (Pasal 124 KUHP)

e. Pembunuhan berencana terhadap Negara sahabat (Pasal 140 ayat (3) KUHP)

f. Pembunuhan berencana (Pasal 340 KUHP)

g. Pencurian dengan kekerasan secara bersekutut mengakibatkan luka berat atau mati (Pasal 365 ayat (4) KUHP

h. Pembajakan laut mengakibatkan kematian (Pasal 444 KUHP)

i. Kejahatan penerbangan dan sarana penerbangan (Pasal $149 \mathrm{~K}$ ayat (2) dan Pasal 1490 ayat (2) KUHP)

Di luar KUHP ada beberapa peraturan perundang-undangan yang mengatur hukuman mati diantaranya :

1. Tindak pidana narkoba (undang - undang nomor 22 tahun 1997)

2. Pelanggaran HAM berat ( Undang - Undang nomor 26 tahun 2000 )

3. Terorisme ( undang - undang nomor 15 tahun 2000)

4. Tindak pidana korupsi

5. Tindak pidana ekonomi. 
Dalam penerapannya hukuman mati mengandung perdebatan pro dan kontra. Beberapa pihak sepakat hukuman mati tetap diterapkan dengan maksud agar terjadi sifat jera, akan tetapi bagi pihak yang kontra berpendapat penerapan hukuman mati tidak sesuai dengan tujuan hukum pidana reedukasi dan resosialisasi.

Pihak yang pro hukuman mati berpendapat bahwa pidana mati dibenarkan dalam hal - hal tertentu, yaitu apabila si pelaku telah memperlihatkan dengan perbuatannya dia adalah orang yang membahayakan kepentingan umum dan oleh karena itu untuk menghentikan kejahatannya dibutuhkan suatu hokum yang tegas yaitu hukuman mati.

Pihak yang kontra terhadap pidana mati berpendapat bahwa hukuman mati sebenarnya tidak perlu. Apabila hukuman mati telah dijalankan maka tidak bisa memberi harapan baik revisi atas pidananya maupun perbaikan atas dirinya sendiri. Karena salah satu tujuan adanya pidana adalah untuk mendidik atau memberikan rasa jera agar si pelaku tidak mengulangi lagi tindakan yang sama. Sedangkan untuk tujuan pidana mati selalu ditujukan kepada khalayak ramai agar mereka dengan ancaman hukuman akan merasa takut apabila melakukan perbuatan perbuatan kejam.

Walaupun di Indonesia masih diberlakukan hukuman mati akan tetapi di dalam KUHP telah memberikan isyarat bahwa pidana mati tidak mudah untuk dijatuhkan. Menjatuhkan pidana 
mati harus dengan hati - hati, tidak boleh gegabah. Isyarat yang diberikan KUHP agar hukuman mati tidak mudah dan sering dijatuhkan yaitu dengan cara bahwa bagi setiap kejahatan yang dipidana mati selalu diancamkan pidana alternativenya. Yaitu pidana penjara seumur hidup atau pidana sementara waktu sekurang - kurangnya 20 tahun penjara. Contohnya pasal 365 (4) dan pasal 340 KUHP

Pasal 340 KUHP

"Barangsiapa dengan sengaja dan dengan rencana terlebih dahulu merampas nyawa orang lain, diancam karena pembunuhan dengan rencana, dengan pidana mati atau pidana seumur hidupatau selama waktu tertentu, paling lama dua puluh tahun".

Pasal 364 ayat 4

"Diancam dengan pidana mati atau pidana seumur hidup atau selama waktu tertentu paling lama dua puluh tahun, jika perbuatan mengakibatkan luka berat atau kematian dan dilakukan oleh dua orang atau lebih dengan bersekutu, disertai pula oleh salah satu hal yang diterangkan dalam nomor 1 dan 3."

Tata cara pelaksanaan hukuman mati diatur dalam Penetapan Presiden Republik Indonesia nomor 2 tahun 1964 tentang Tata Cara Pelaksanaan Pidana mati yang dijatuhkan oleh Pengadilan di Lingkungan Peradilan Umum dan Militer.

\section{Ad. 2 Pidana Penjara}


Pidana penjara adalah pidana yang berupa pengekangan kemerdekaan yang dijatuhkan oleh hakim kepada terpidana. Pidana penjara ialah pokok sistem hukuman di Indonesia. Pertama kali pidana penjara diterapkan oleh orang Indonesia sejak 1918, sejak berlakunya KUHP di Indonesia. Pidana penjara dibedakan atas pidana seumur hidup dan pidana penjara selama waktu tertentu. Pidana penjara selama waktu tertentu paling pendek adalah satu hari sedangkan paling lama adalah 15 tahun berturut - turut sebagaimana diatur dalam pasal 12 ayat (1) dan ayat (2) KUHP. Jangka waktu 15 tahun dapat ditambah menjadi 20 tahun dalam hal sebagai alternative pidana mati, terjadinya perbarengan (concursus) atau pengulangan (residive) serta dalam hal terpenuhinya ketentuan pada pasal 52 dan 52a KUHP.

Pasal 12:

(1) Pidana penjara adalah seumur hidup atau selama waktu tertentu

(2) Pidana penjara selama waktu tertentu paling pendek satu hari dan paling lama lima belas tahun berturut - turut.

(3) Pidana penjara selama waktu tertentu boleh dijatuhkan untuk dua puluh tahun berturut - turut dalam hal kejahatan yang pidananya hakim boleh memilih antara pidana mati, pidana seumur hidup, dan pidana penjara selama waktu tertentu; begitu juga dalam hal batas lima belas tahun dilampaui sebab tambahan pidana karena perbarengan (concursus), pengulangan (residive) atau karena yang ditentukan dalam pasal 52.

(4) Pidana penjara selama waktu tertentu sekali - kali tidak boleh melebihi dua puluh tahun. 
Pidana penjara disebut sebagai pidana hilang kemerdekaan, bukan saja dalam arti sempit bahwa ia tidak merdeka berpergian, tetapi narapidana tersebut kehilangan hak-hak tertentu : ${ }^{16}$

a. Hak untuk memilih dan dipilih

b. Hak untuk memangku jabatan publik

c. Hak untuk bekerja pada perusahaan-perusahaan

d. Hak untuk mendapatkan perizinan-perizinan tertentu

e. Hak untuk mengadakan asuransi hidup

f. Hak untuk tetap dalam ikatan perkawinan

g. Hak untuk kawin

h. Beberapa hak sipil lainnya.

Dalam menjalani pidana penjara di Lembaga Pemasyarakatan narapidana wajib menjalankan pekerjaan pekerjaan yang diwajibkan kepadanya menurut ketentuan pelaksanaan yang diatur dalam pasal 29 KUHP. Kewajiban bekerja bagi narapidana dapat juga dilakukan di luar lembaga pemasyarakatan, kecuali bagi narapidana tertentu yang ditentukan dalam pasal 25 KUHP yaitu

1. Orang yang dijatuhi hukuman seumur hidup

2. Para wanita

3. Orang - orang yang menurut pemeriksaan dokter tidak boleh menjalankan tugas yang demikian.

\section{Ad. 3 Pidana Kurungan}

${ }^{16}$ Andi Hamzah, Op, Cit 190 
Pidana kuruangan merupakan hukuman yang paling ringan dibanding dengan pidana penjara. Hukuman kurungan dapat dilaksanakan dengan batasan paling sedikit satu hari dan paling lama satu tahun. Lamanya masa kurangan diatur dalam Pasal 18 KUHP.

Pidana kurungan adalah sutau pidana yang bersifat perampasan kemerdekaan terhadap seseorang untuk jangka waktu tertentu. Hukuman pidana penjara dan kurungan kedua duanya adalah bentuk pemidanaan dengan menahan kebebasan seseorang karena melakukan tindak pidana. Keduanya merupakan pidana pokok yang dijatuhkan oleh hakim. Sedangkan perbedaannya adalah :

1. Pidana penjara dikenakan kepada orang yang melakukan kejahatan sedangkan pidana kurungan dikenakan kepada orang yang melakukan tindak pidana ringan seperti pelanggaran (lihat buku ketiga KUHP tentang pelanggaran ). Atau sebagai pengganti pidana denda yang tidak bisa dibayarkan (pasal 30 ayat 2 KUHP) dan kejahatan kealpaan.

2. Pelaksanaan hukuman penjara dan hukuman kurungan dapat saja dapat saja dilakukan tempat yang sama asalkan terpisah. Maksudnya orang yang menjalani hukuman penjara maupun hukuman kurungan berada dalam satu tempat (lembaga pemasyarakatan) tetapi sel mereka berbeda dan tidak dicampur.

3. Pidana penjara dapat dikenakan selama seumur hidup atau waktu tertentu Antara satu hari sampai 20 tahun berturut - 
turut sedangkan pidana kurungan dikenakan paling pendek satu hari dan paling lama satu tahun (pasal 18 ayat 1 KUHP) tetapi dapat diperpanjang pemberatan paling lama satu tahun 4 bulan, serta dikenakan kewajiban kerja tetapi lebih ringan daripada kewajiban kerja terpidana penjara.

Bentuk lain dari sifat lebih ringan hukuman kurungan dibanding hukuman penjara adalah :

1. Terpidana penjara dapat dibawa ke tempat lain untuk dipindahkan dan tidak boleh menolak. Sedangkan terpidana kurungan berdasarkan pasal 21 KUHP tidak boleh dipindahkan tanpa mendapat persetujuan dari terpidana.

2. Berdasarkan pasal 23 KUHP terpidana kurungan masih bisa mendapatkan uang saku diluar upah kerja wajib, sebagai bekal saat ia keluar dari penjara dan pulang.

\section{Ad. 4 Pidana Denda}

Pidana denda adalah pidana yang dijatuhkan oleh hakim kepada terpidana berupa kewajiban membayar sejumlah uang. Jumlah denda dalam kategori tertentu dapat diangsur. Pidana denda diancamkan pada jenis pelanggaran (buku ketiga) baik secara alternative maupun berdiri sendiri, jenis - jenis kejahatan ringan maupun kejahatan culpa. Pidana denda sering diancamkan sebagai alternative dari pidana kurungan. Apabila tidak membayar uang denda yang telah diputuskan konsekwensinya adalah harus menjalani kurungan (kurungan pengganti denda, pasal 30 ayat 2 sebagai pengganti dari pidana denda. Sedangkan batas waktu untuk pembayaran denda adalah ditetapkan dalam pasal 27 ayat 1 . Sedangkan ayat 2 menyatakan bahwa dalam hal 
ada alasan kuat jangka waktu sebagaimana tersebut diatas dapat diperpanjang paling lama satu bulan. Uang denda yang dibayarkan oleh terpidana menjadi milik Negara ( pasal 24).

Pasal 30 ayat 2 :

" Jika pidana denda tidak dibayar, ia diganti dengan pidana kurungan"

\section{Ad. 5 Pidana Tutupan}

Pidana tutupan ditambahkan ke dalam Pasal 10 KUHP melalui Undang-Undang No. 20 Tahun 1946. Pasal 2 ayat (1) Undang-Undang ini. Secara sederhana pidana tutupan ini adalah karantina di tempat tertentu atau pengasingan. Dalam praktik belum ada putusan pengadilan terkait dengan pidana tutupan ini. Berdasarkan Undang-Undang No. 20 Tahun 1946, pidana tutupan diterapkan dalam peristiwa-peristiwa yang ada unsur politiknya. Mr. Utrecht dalam buku hokum pidana II berpendapat rumah tutupan bukan suatu penjara biasa tetapi merupakan suatu tempat yang lebih baik dari penjara biasa selain orang yang dihukum bukan orang biasa, perlakuan terhadap hukuman tutupan juga istimewa.

Menurut Andi Hamzah dalam azas - azas hukum pidana (hal 191) pidana tutupan disediakan bagi para politisi yang melakukan kejahatan yang disebabkan oleh ideology yang dianutnya. Tetapi dalam praktek dewasa ini tidak pernah ketentuan tersebut diterapkan.

\section{B Pidana Tambahan}


Pidana tambahan adalah pidana yang bersifat penambahan atas hukuman pokok. Tidak bisa berdiri sendiri dan bersifat fakultatif (dapat dijatuhkan akan tetapi tidak harus). Pidana tambahan dapat dijatuhkan bersamaan dengan pidana pokok. Ada tiga jenis pidana tambahan yaitu pencabutan hak-hak tertentu, perampasan barang tertentu dan pengumuman putusan hakim.

\section{Ad. 1 Pencabutan Hak-Hak Tertentu}

Pidana tambahan berupa pencabutan hak-hak tertentu tidak berarti hak-hak terpidana dapat dicabut. Pencabutan ini tidak termasuk pencabutan hak-hak kehidupan dan hak-hak sipil (perdata) dan hak-hak ketatangeraan, hal ini diatur dalam Pasal 35 KUHP secara limitatif. Terkait dengan lamanya secara mutlak diserahkan kepada hakim sebagaimana Pasal 38 KUHP. Hukuman ini bersifat tindakan daripada hukuman.

Pasal 35 KUHP :

(1) Hak - hak terpidana yang dengan putusan hakim dapat dicabut dalam hal - hal yang ditentukan dalam kitab undang undang ini atau dalam aturan umum lainnya ialah ;

1. Hak memegang jabatan pada umumnya atau jabatan yang tertentu;

2. Hak memasuki angkatan bersenjata;

3. Hak memilih dan dipilih dalam pemilihan yang diadakan berdasarkan aturan - aturan umum.

4. Hak menjadi penasehat hokum atau pengurus atas penetapan pengadilan, hak menjadi wali, wali pengawas, pengampu atau pengampu pengawas, atas orang yang bukan anak sendiri 
5. Hak menjalankan kekuasaan bapak, menjalankan perwalian atau pengampuan atas anak sendiri;

6. Hak menjalankan mata pencaharian tertentu.

(2) Hakim tidak berwenang memecat seorang pejabat dari jabatannya, jika dalam aturan - aturan khusus ditentukan penguasa lain untuk pemecatan itu.

\section{Ad.2 Perampasan Barang Tertentu}

Pidana perampasan merupakan pidana kekayaan, seperti pidana denda. Perampasan barang tertentu dimaksudkan barang yang dirampas dari si terpidana adalah barang hasil tindak pidana atau barang milik terpidana yang dipergunakan untuk melakukan tindak pidana. Perampasan barang tertentu ini diatur dalam Pasal 39 KUHP.

\section{Ad. 3 Pengumuman Putusan Hakim}

Putusan hakim nharus dibacakan dalam siding tertentu. Namun dalam keadaan tertentu hakim bias berpendapat bahwa putusan hakim harus disebarluaskan. Pidana tambahan pengumuman putusan hakim dimaksudkan agar masyarakat umum lebih berhati-hati terhadap si terpidana. Pengumuman putusan hakim harus dimuat dalam putusan, hal ini diatur dalam Pasal 43 KUHP.

Pasal 43 KUHP :

"Apabila hakim memerintahkan supaya putusan diumumkan berdasarkan kitab undang - undang ini atau aturan - aturan umum 
lainnya,maka ia harus menetapkan pula bagaimana cara melaksanakan perintah ituatas biaya terpidana"

\section{SOAL - SOAL LATIHAN}

1.Sebutkan dan jelaskan secara rinci jenis - jenis pidana

2. Uraikan secara rinci perbedaan antara pidana pokok dan pidana tambahan.

\section{REFERENSI}

Hamzah Andi, 2012, Asas-asas Hukum Pidana di Indonesia dan perkembangannya, Jakarta, sofmedia,

Bambang Waluyo, Pidana dan Pemidanaan, Sinar Grafika, Jakarta, 2008. 


\section{BAB IV \\ PENYERTAAN}

\section{SUB KOMPETENSI}

1. Pengertian penyertaan

2. Pembuat/dader Tindak Pidana

3. Pembantu Tindak Pidana

\section{TUJUAN PEMBELAJARAN}

Mahasiswa pada akhir pembelajaran di level kompetansi ini mampu menjelaskan pengertian penyertaan serta mampu menjelaskan pelaku tindak pidana dan pembantu tindak pidana .

\section{INDIKATOR HASIL BELAJAR}

1. Mahasiswa dapat menjelaskan tentang pengertian penyertaan

2. Mahasiswa dapat menjelaskan pelaku tindak pidana

3. Mahasiswa dapat menjelaskan pembantu tindak pidana. 


\section{MATERI}

D. Pengertian Penyertaan (Deelneming)

Tindak pidana dapat dilakukan oleh beberapa orang secara bersama-sama. Keterlibatan dari beberapa orang di dalam suatu tindak pidana merupakan bentuk kerja sama yang berlainan sifat dan bentuknya sesuai dengan peran masing-masing. Konsep ini dikenal dengan konsep penyertaan.

Penyertaan di atur dalam pasal 55 - 62 KUHP. Menurut Moelyatno penyertaan dirumuskan bahwa terdapat penyertaan jika dalam satu tindak pidana dilakukan oleh dua orang atau lebih. Tindak pidana yang dilakukan oleh beberapa orang yang tersangkut. Jadi bukan tindak pidana yang dilakukan seorang diri. Akan tetapi tidak semua yang melakukan tindak pidana disebut sebagai peserta atau pelaku. Tetapi hanya sebagai pembatu dalam melakukan tindak pidana.

S.R Sianturi memberikan pengertian penyertaan adalah suatu tindak pidana yang dilakukan oleh dua orang atau lebih. Dua orang atau lebih turut ambil bagian dalam mewujudkan tindak pidana. ${ }^{17}$ Penyertaan diterapkan dalam hukum pidana dipergunakan untuk dua hal yaitu sebagai dasar memperluas dapat dipidananya orang dan sebagai dasar memperluas dapat dipidananya perbuatan.

\section{E. Pembuat (Dader) dan Bentuk-bentuk Penyertaan}

Secara normatif Pasal 55 dan 56 KUHP mengatur daders dan medeplichtige. Dalam doktrin ilmu hukum pidana penyertaan

\footnotetext{
17 SR Sianturi, Asas-asas Hukum Pidana dan Penerapannya, Alumni Ahaem Patehaem, Jakarta, 1983, hal. 338.
} 
menurut sifatnya dibagi menjadi dua yaitu deelneming yang berdiri sendiri dan deelneming yang tidak berdiri sendiri. Dari rumusan Pasal 55 penyertaan dibagi menjadi :

1. Pelaku/pleger 2. yang menyuruh lakukan/doenpleger

3. Turut serta /medeplegen. 4. Penganjur/uitlokker

Sedangkan rumusan membantu :

1. Membantu saat dilakukannya kejahatan

2. Membantu saat kejahatan belum dilakukan.

Dengan tegas Pasal 55 KUHP mengatur pembuat, sedangkan Pasal 56 mengatur pembantu.

\section{Ad. 1 Pelaku(Pleger)}

Pelaku adalah orang yang melakukan suatu perbuatan yang memenuhi unsur - unsur pidana. Pelaku inilah yang paling bertanggungjawab atas kejahatan yang dilakukan. Karena dengan perbuatan yang dilakukan maka tindak pidana terjadi. Sebaliknya tanpa perbuatannya maka tindak pidana tidak akan terjadi. Dengan perbuatannya maka akan timbul akibat yang dilarang oleh undang undang. Dalam konsep hukum pidana dikenal dengan pembuat (dader).

Pembuat (dader) merupakan bentuk umum dari pleger. Pleger merupakan spesies dari dader. Menurut Simons pleger adalah petindak tunggal (de allen dader). Tetapi, pendapat Simons ini harus dimaknai dalam konsep penyertaan, bukan tindak pidana dengan pelaku tunggal. 


\section{Ad. 2 Yang Menyuruh lakukan (Doenpleger)}

Yang menyuruh lakukan adalah orang yang melakukan tindak pidana secara tidak langsung. Disebut pelaku tidak langsung karena memang tidak langsung melakukan tindak pidana sendiri tetapi dengan perantara orang lain. Peranta atau orang lain ini dipakai sebagai alat.

Pada doenplagen harus memenuhi unsur sebagai berikut :

1. Perantara yang dipakai adalah manusia

2. Perantara yang dipakai "berbuat" artinya melakukan perbuatan

3. Perantara yang dipakai "Tidak dapat dipertanggung jawabkan secara hukum"

Unsur pada point ketiga merupakan tanda ciri dari doenplagen.

Hal yang menyebabkan perantara tidak dapat dipertanggungjawabkan seperi tidak sempurna pertumbuhan jiwanya atau rusak jiwanya, berbuat karena daya paksa, dll.

\section{Ad. 3 orang yang Turut Serta Melakukan (Medepleger)}

Orang yang turut serta melakukan (medepleger) adalah orang yang dengan sengaja turut berbuat atau turut mengerjakan terjadinya sesuatu. Kualitas masing - masing pelaku tindak pidana adalah sama sehingga masing - masing pelaku dijatuhi hukuman yang sama pula.

Contoh :

Ada 3 orang pencopet didalam bis yang saling bekerjaama ( $A, B$ dan $C$ ). Dalam menjalankan aksinya mereka membagi tugas. $A$ manabrak orang yang menjadi sasaran, B mengambil dompet - Setelah mendapatkan dompet langsung menyerahkan kepada $\mathrm{C}$ dan $\mathrm{C}$ yang membawa kabur hasil mencopet. 
Syarat perbuatan dikategorikan turut serta adalah :

1. Ada kerja sama yang dikehendaki.

Kerjasama ini bertujuan untuk mencapai hasil yang sama.

Tidak ada turut serta bila tidak ada kehendak yang sama.

Misalnya A menghendaki melakukan penganiayaan sedangkan

$B$ menghendaki matinya seseorang.

2. Pelaksanaan dilakukan bersama.

Yang paling penting adalah harus ada kerjasama yang kuat.

\section{Ad. 4 Penganjur (Uitlokker)}

Orang yang menggerakkan orang lain untuk melakukan tindak pidana dengan menggunakan sarana yang ditentukan oleh undang - undang secara limitative yaitu :

1. Memberi atau menjanjiakan sesuatu 2. Menyalahgunakan kekuasaan atau martabat 3. Kekerasan 4. Ancaman atau penyesatan dengan memberi kesempatan, sarana atau prasarana.

Hukuman untuk penganjur adalah sama dengan pelaku ditambah sepertiga. Contoh pembunuhan dipidana 15 tahun penjara apabila pembunuhan itu ada orang yang menganjurkan maka hukuman untuk penganjur adaka 15 tahun + seperiga dari 15 tahun ).

Perbedaan Antara penganjuran dan menyuruh lakukan adalah : Penganjuran :

$>$ Menggerakkannya dengan menggunakan sarana tertentu yang diatur oleh undang - undang 
$>$ Pelaku yang dianjurkan dapat dipertanggungjawabkan Menyuruh lakukan :

$>$ Sarana untuk menggerakkan tidak ditentukan secara limitative oleh undang - undang

$>$ Pelaku yang disuruh tidak dapat dipertanggungjawabkan.

\section{F. Pembantu Tindak Pidana (Medeplichtige)}

1. Pengertian Pembantuan

Pembantuan secara normatif diatur dalam Pasal 56 KUHP.

Untuk memahami makna pembantuan maka perlu kiranya diperhatikan rumusan Pasal 57 ayat (4) KUHP "Dalam menentukan hukuman bagi pembantu, hanya diperhatikan perbuatan yang sengaja memudahkan atau diperlancar oleh pembantu itu serta akibatnya".

Pembantu hanya bersifat asesoir. Ini berarti pembantu ada apabila terdapat orang yang melakukan tindak pidana. tindak pidana . Pembantu hanya menunjang terjadinya tindak pidana.

2. Bentuk-bentuk pembantuan :

a. Pembantu pada saat dilakukannya tindak pidana Contoh kasus :

Perampok melakukan perampokan. Kemudian perampok bekerjasama dengan tukang kebun. Tukang kebun tersebut membantu pada saat tindak pidana terjadi yaitu dengan cara membukakan pintu rumah majikannya. Dengan dibukakan pintu maka perampok dapat dengan mudah masuk rumah dan melakukan aksinya 
b. Pembantu pada saat tindak pidana belum dilakukan dengan memberi kesempatan, saran atau keterangan Pembantuan pada saat kejahatan sebelum dilaksanakan dilakukan dengan cara memberi kesempatan, sarana atau keterangan.

Contoh kasius :

Seorang pembantu rumah tangga berkomplot dengan pencuri yang akan melakukan pencurian dirumah majikannya. Pembantu tersebut sebelum terjadinya pencurian memberikan keterangan bahwa pada jam 12.00 majikannya baru menuju kamar tidur, majikannya biasanya tidur dikamar depan, dan tempat penyimpanan harta yang berharga.

\section{SOAL - SOAL LATIHAN}

1. Jelaskan pengertian penyertaan

2. Sebutkan dan jelaskan yang dimaksud dengan pembuat tindak pidana

3. Sebutkan dan jelaskan yang dimaksud pembantu tindak pidana. 


\section{REFERENS|}

Sianturi SR, 1989 Asas-asas Hukum Pidana di Indonesia dan Penerapannya, Jakarta Alumni AHAEM-PETAHAEM, 


\section{GABUNGAN TINDAK PIDANA}

\section{SUB KOMPETENSI}

1. Pengertian Gabungan Tindak Pidana

2. Penggabungan Tindak Pidana dalam KUHP

3. Jenis - Jenis Gabungan Tindak Pidana

4. Syarat - syarat Gabungan Tindak Pidana

5. System Pemidanaan Gabungan Tindak Pidana

\section{TUJUAN PEMBELAJARAN}

Mahasiswa pada akhir pembelajaran di level kompetensi ini mampu memahami dan penjelaskan pengertian gabungan tindak pidana, penggabungan pidana dalam KUHP, syarat - syarat dari gabungan tindak pidana, dan sistem pemidanaan gabungan tindak pidana.

\section{INDIKATOR HASIL BELAJAR}

1. Mahasiswa dapat menjelaskan pengertian gabungan tindak pidana

2. Mahasiswa dapat menjelaskan penggabungan tindak pidana dalam KUHP

3. Mahasiswa dapat menyebutkan syarat - syarat gabungan tindak pidana

4. Mahasiswa dapat menjelaskan system pemidanaan dalam gabungan tindak pidana

\section{MATERI}

F. Pengertian Gabungan Tindak Pidana

1. Pengertian 
Gabungan tindak pidana merupakan ajaran mengenai caracara untuk memperhitungkan dalam menetapkan berat ringannya pemidanaan bagi pelaku tindak pidana beberapa kali. Penggabungan perkara ini juga diatur dalam Pasal 141 KUHAP "Penuntut Umum dapat melakukan penggabungan perkara dan membuatnya dalam satu surat dakwaan, apabila pada waktu yang sama atau hampir bersamaan ia menerima beberapa berkas perkara dalam hal :

a. Beberapa tindak pidana yang dilakukan oleh seorang yang sama dan kepentingan pemeriksaan tidak menjadikan menghambat terhadap penggabungannya.

b. Beberapa tindak pidana yang bersangkut-paut satu sama lain.

c. Beberapa tindak pidana yang tidak bersangkut-paut satu dengan yang lain, akan tetapi yang satu dengan yang lain itu ada hubungannya, yang dalam hal ini penggabungan tersebut perlu bagi kepentingan pemeriksaan.

\section{G. Penggabungan Tindak Pidana dalam KUHP}

Ketentuan yang mengatur tentang gabungan tindak pidana dalam KUHP sebagai berikut :

a. Pengaturan tentang perbarengan/gabungan satu perbuatan (endaadsche samenloop/concursus idealis.

KUHP mengaturnya dalam Pasal 63 KUHP sebagai berikut : Pasal 63

Bila suatu tindak pidana masuk dalam lebih sari satu aturan pidana, maka yang dikenakan hanya salah satu diantara 
aturan-aturan itu, bila pidananya berbeda-beda, maka yang dikenakan adalah yang memuat ancaman pidana pokok yang paling berat.

Bila suatu perbuatan yang masuk dalam suatu aturan pidana yang umum, diatur juga dalam aturan pidana yang khusus maka yang diterapkan adalah yang khusus.

a. Pengaturan tentang Perbuatan Berlanjut (voorgezette Handeling).

Tentang hal ini diatur dalam ketentuan Pasal 64 KUHP.

b. Pengaturan tentang perbarengan Beberapa Perbuatan (Meerdaadsche Samenloop/Concursus Realis)

Tentang hal ini diatur dalam Pasal 65-71 KUHP.

\section{H. Jenis - Jenis Gabungan Tindak Pidana}

\section{Bentuk Gabungan Kejahatan}

Merujuk pada KUHP maka secera sederhana perbarengan atau gabungan tindak pidana dapat dibagi menjadi tiga golongan besar :

1. Eendaadsche samenloop atau concursus idealis, sebagai perbarengan tindak pidana dalam satu perbuatan yang terdiri atas :

a. Concursus idealis homogenius sebagai perbarengan tindak pidana sejenis dalam satu perbuatan.

b. Consursus idealis heterogenius sebagai perbarengan tindak pidana tidak sejenis dalam satu perbuatan.

c. Voortgezette Handeling merupakan gabungan tindak pidana sebagai berbuatan berlanjut 
d. Meerdaadsche samenloop atau concursus realis sebagai perbarengan tindak pidana dalam beberapa perbuatan.

2. Concosrsus realis homogenius sebagai perbarengan tindak pidana sejenis dalam beberapa perbuatan.

3. Concorsus realis heterogenius sebagai perbarengan tindak pidana tidak sejenis dalam beberapa perbuatan.

\section{Syarat - syarat gabungan Tindak Pidana}

a. Ada dua / lebih tindak pidana yang dilakukan.

b. Dua/lebih tindak pidana tersebut belum ada yang diadili

c. Dua /lebih tindak pidana tersebut akan diadili sekaligus.

\section{Sistem pemidanaan Gabungan Tindak Pidana}

1. Sistem absorbsi

Apabila seseorang melakukan beberapa perbuatan yang merupakan beberapa delik yang masing - masing diancam dengan pidana yang berbeda, maka menurut sistem ini hanya dijatuhkan satu pidana saja, yaitu pidana yang terberat walaupun orang tersebut melakukan beberapa delik.

Contoh kasus pertama :

- Merusak pagar dan jendela hukuman 1 tahun penjara

- Penganiayaan hukuman dua tahun penjara

- Pencurian hukuman penjara dua tahun enam bulan penjara.

Maka jika dipakai sistem ini hukuman yang dijatuhkan adalah dua tahun enam bulan penjara. 


\section{Sistem kumulasi}

Apabila seseorang melakukan beberapa perbuatan yang merupakan beberapa delik yang diancam dengan pidana sendiri - sendiri, maka menurut sistem ini tiap - tiap pidana yang diancamkan terhadap delik - delik yang dilakukan oleh orang itu semuanya dijatuhkan.

Jika kita mencontoh kasus diatas maka hukuman yang dijatuhkan adalah :

Merusak pagar dan jendela (satu tahun) + penganiayaan (dua tahun) + pencurian (dua tahun enam bulan ).

3. Sistem absorbsi diperberat

Menurut sistem ini pada hakekatnya hanya dapat dijatuhkan satu pidana saja yakni yang terberat, atetapi dalam hal ini diperberat dengan menambah $1 / 3$ (sepertiga)

Mengacu kasus diatas maka pidana yang dijatuhkan adalah dua tahun enam bulan +10 bulan

4. Sistem kumulasi terbatas.

Menurut sistem ini semua pidana yang diancamkan terhadap masing - masing delik dijatuhkan semuanya. Akan tetapi jumlah pidana itu harus dibatasi, yaitu jumlahnya tidak boleh melebihi dari pidana terberat ditambah $1 / 3$ (sepertiga). Akan tetapi boleh kurang dari sepertiga 
Perbedaan antara sistem absorbsi diperberat dengan sistem kumulasi terbatas adalah :

Apabila absorbsi diperberat pasti ditambah sepertiga dari hukuman yang terberat akan tetapi jika kumulasi terbatas tidak harus sepertiga tetapi maksimal sepertiga.

\section{SOAL - SOAL LATIHAN}

1. Jelaskan pengertian gabungan tindak pidana

2. Jelaskan penggabungan tindak pidana menurut KUHP

3. Sebutkan syarat - syarat gabngan tindak pidana

4. Sebutkan sistem pemidanaan dalam gabungan tindak pidana

\section{REFERENSI}

Lamintang Fransiscus Theojunior, 2016, Dasar - Dasar Hukum Pidana di Indonesia, Jakarta, sinar Grafika,

Ruba'I Masruchin, 2015, Buku Ajar Hukum Pidana, Malang, Media Nusa Creative,

Moelyatno, 2008, Asas - Asas Hukum Pidana, Rieneka Cipta, Jakarta,

Rasyid Ariman, Fahmi Raghib, 2016, Hukum Pidana, Malang Setara Press, 


\section{BAB VI \\ PERTANGGUNGJAWABAN PIDANA}

\section{SUB KOMPETENSI}

1. Pengertian Pertanggungjawaban Pidana

2. Alasan Pemaaf

3. Alasan Pembenar

\section{TUJUAN PEMBELAJARAN}

Mahasiswa pada akhir pembelajaran di level kompetensi ini mampu memahami dan menjelaskan pengertian tanggung jawab pidana, Alasan Pemaaf dan alasan pembenar

INDIKATOR HASIL BELAJAR 
1. Mahasiswa dapat menjelaskan pengertian tanggungjawab pidana

2. Mahasiswa dapat menjelaskan Alasn pemaaf beserta macam - macamnya

3. Mahasiswa dapat menjelaskan alasan pembenar beserta macam - macamnya

\section{MATERI}

\section{A Pengertian Pertanggungjawaban Pidana}

Pertanggungjawaban pidana dalam bahasa Belanda disebut dengan teorekenbaardheit, sedangkan dalam bahasa Inggris disebut dengan criminal responbility. Pertanggungjawaban pidana adalah suatu mekanisme untuk menentukan apakah seseorang terdakwa atau tersangka dipertanggungjawabkan atas suatu tindakan pidana yang terjadi atau tidak. Untuk dapat dipidananya di pelaku, disyaratkan bahwa tindak pidana yang dilakukannya itu memenuhi unsur-unsur yang telah ditentukan dalam undangundang.

Pertanggungjawaban pidana mengandung makna bahwa setiap orang yang melakukan tindak pdana atau melawan hukum, sebagaimana dirumuskan dalam undang-undang, maka orang tersebut patut mempertanggungjawabkan perbuatan sesuai dengan kesalahannya. Dengan kata lain orang yang melakukan perbuatan pidana akan mempertanggungjawabkan perbuatan tersebut dengan pidana apabila yang bersangkuta mempunyai kesalahan, seseorang mempunyai kesalahan apabila pada waktu melakukan perbuatan dilihat dari segi masyarakat menunjukan 
pandangan normative mengenai kesalahan yang telah dilakukan oleh orang tersebut. ${ }^{18}$

Pertanggungjawaban pidana diterapkan dengan pemidanaan yang bertujuan untuk mencegah dilakukannya tindak pidana dengan mengekan norma hukum demi pengayoman masyarakat; menyelesaikan konflik yang ditimbulkan tindak pidana, memulihkan keseimbangan, mendatangkan rasa damai dalam masyarakat, memasyarakatkan terpidana dengan mengadakan pembinaan sehingga menjadi orang baik dan membebaskan rasa bersalah pada terpidana.

Menurut teori hukum pidana, ada sejumlah teori dan doktrin yang berkembang untuk menentukan pertanggungjawaban pidana dari seseorang pelaku tindak pidana. Berikut adalah beberapa pandangan tentang kemampuan bertanggung jawab menurut beberapa pakar yang telah menjadi acuan umum di Indonesia. ${ }^{19}$

Unsur-unsur pertanggungjawaban pidana menurut ahli sebagai berikut :

1. Pompe

a. Kemampuan berpikir pembuat (dader) yang memungkinkan ia menguasi pikirannya, yang memungkinkan ia menentukan perbuatannya.

b. Oleh sebab itu, ia dapat menentukan akibat perbuatannya

c. Sehingga ia dapat menentukan kehendaknya sesuai dengan pendapatnya.

\footnotetext{
18 Moeljatno, Op Cit, hal 41.

19 Prodjodikoro Wirjono , 1986, Asas-asas Hukum Pidana Indonesia, Bandung ,PT. Eresko, hal. 55
} 
2. Van Hamel

a. Untuk memahami lingkungan kenyataan perbuatan sendiri

b. Untuk menyadari perbuatannya sebagai suatu yang tidak diperbolehkan oleh masyarakat

c. Terhadap perbuatannya dapat menentukan kehendaknya.

Pertanggungjawaban pidana diarahkan secara langsung kepada pemidanaan petindak (pelaku), apabila perbuatannya telah memenuhi unsur-unsur yang ditentukan dalam undang-undang. Maka seseorang akan dimintai pertanggungjawaban pidana atas tindakan-tindakannya apabila tindakan tersebut melawan hukum. Dilihar dari kemampuan bertanggung jawab maka seseorang yang mampu bertanggungjawab yang dapat dimintai pertanggungjawaban pidana.

Kemampuan bertanggung jawab dilihat dari : $:^{20}$

a. Keadaan jiwanya

- Tidak terganggu oleh penyakit terus menerus atau sementara waktu (temporal)

- Tidak cacat dalam pertumbuhan (gagu, idiot, imbisil dan sebagainya.

- Tidak terganggu karena terjut, hipnotisme, amarah yang meluap, pengaruh bawah sadar.

b. Kemampuan jiwanya

- Dapat menginsyafi hakikat dari tindakannya

- Dapat menentukan kehendaknya atas tindakan tersebut, apakah akan dilaksanakan atau tidak.

20 EY Kanter dan SR Sianturi, 2002, Asas-asas Hukum Pidana di Indonesia dan Penerapannya, Storia Grafika, Jakarta, hal 249. 
- Dapat mengetahui ketercelaan dari tindakan tersebut.

Pertanggungjawaban pidana dimaksudkan untuk menentukan apakah seseorang tersangka / terdakwa dipertanggung jawabkan atas suatu tindak pidana (crime) yang terjadi atau tidak. Seseorang yang melakukan tindak pidana akan tetapi dia tidak dapat dipidana atas perbuatannya karena adanya alasan penghapus pidana.

Alasan yang menghapus pidana dibedakan menjadi :

1. Alasan pemaaf

Yaitu alasan yang menghapuskan kesalahan terdakwa. perbuatan yang dilakukan oleh terdakwa tetap bersifat melawan hukum, jadi tetap merupakan perbuatan pidana, tetapi dia tidak dipidana karena tidak ada kesalahan.

2. Alasan pembenar

Yaitu alasan yang menghapuskan sifat melawan hukumnya perbuatan, sehingga apa yang dilakukan oleh terdakwa lalu menjadi perbuatan yang patut dan benar.

\section{A. Alasan Pemaaf}

Dalam KUHP terdapat beberapa kontrusksi Pasal yang mengatur terkait dengan alasan pemaaf sebagaimana tabel di bawah ini :

\begin{tabular}{|c|c|}
\hline Pasal & Pengaturan \\
\hline 44 & Pelaku yang Sakit/Terganggu Jiwanya \\
\hline
\end{tabular}




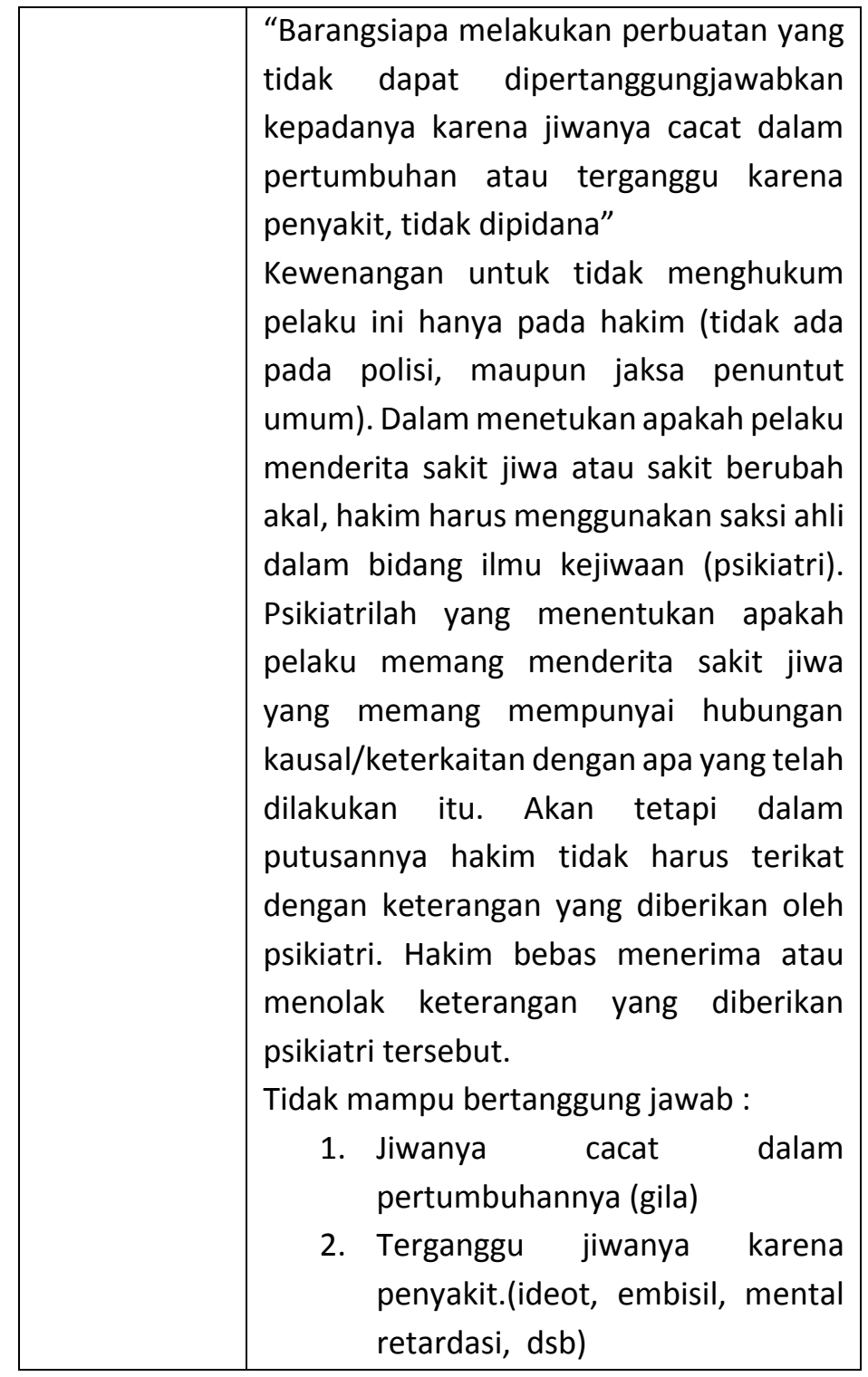




\begin{tabular}{|c|c|}
\hline & $\begin{array}{l}\text { Tidak mampu bertanggung jawab untuk } \\
\text { sebagian ditujukan kepada penderita } \\
\text { penyakit jiwa. } \\
\text { 1. Kleptomania : suka mencuri barang - } \\
\text { barang yang kecil } \\
\text { 2. Pyromania : suka membakar } \\
\text { 3. Claustrophobie : takut berada di } \\
\text { ruang sempit. } \\
\text { 4. Nycotophobia:takut pada kegelapan } \\
\text { 5. Gynophobia : takut pada wanita } \\
\text { 6. Aerophobia : takut di tempat tinggi } \\
\text { 7. Ochlophobia : takut pada orang } \\
\text { banyak } \text { Monophobi : takut sendiri/sunyi. } \\
\text { Seseorang tidak dapat dipertanggung } \\
\text { jawabkan sebatas penyakitnya saja. } \\
\text { Misalnya seseorang yang menderita } \\
\text { kleptomania hanya dibebaskan dari } \\
\text { pidana apabila dia melakukan pencurian } \\
\text { saja. Apabila dia melakukan tindak pidana } \\
\text { lain, maka tetap dipidana. } \\
\text { Kurang mampu bertanggung jawab } \\
\text { Pelaku tetap dianggap mampu } \\
\text { bertanggungjawab, akan } \\
\text { kekurangan itu dipandang sebagai faktor } \\
\text { yang meringankan. }\end{array}$ \\
\hline 48 & $\begin{array}{l}\text { Perbuatan yang dilakukan secara } \\
\text { terpaksa (overmacht) }\end{array}$ \\
\hline
\end{tabular}




\begin{tabular}{|l|l|}
\hline Maksud pasal ini adalah hanya paksaan \\
yang benar-benar tidak dapat dilawan \\
atau dielakan lagi oleh palaku, sehingga \\
karena ada paksaan itulah ia melakukan \\
tindak pidana. Paksaan ini dikenal dengan \\
istilah paksaan absolut.
\end{tabular}




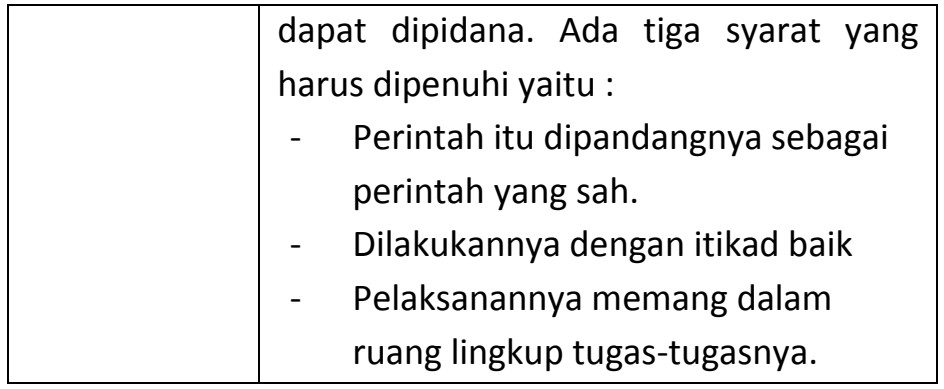

\section{Alasan Pembenar}

Dalam KUHP terdapat beberapa kontruksi Pasal yang mengatur terkait dengan alasan pembenar sebagaimana tabel di bawah ini :

\begin{tabular}{|c|c|}
\hline Pasal & Pengaturan \\
\hline 49 ayat (1) & $\begin{array}{l}\text { Perbuatan yang Dilakukan untuk } \\
\text { Membela Diri (Noodweer). } \\
\text { a. Perbuatan itu dilakukan karena untuk } \\
\text { membela badan/tubuh kehormatan } \\
\text { atau harta benda milik sendiri atau } \\
\text { orang lain. } \\
\text { b. Perbuatan itu dilakukan atas } \\
\text { serangan yang melawan hukum yang } \\
\text { terjadi saat itu juga. Bisa dikatakan } \\
\text { perbuatan itu dilakukan setelah } \\
\text { adanya serangan yang mengancam, } \\
\text { bukan perbuatan yang ditujukan } \\
\text { untuk mempersiapkan sebelum } \\
\text { adanya atau terjadinya serangan dan }\end{array}$ \\
\hline
\end{tabular}




\begin{tabular}{|c|c|}
\hline & $\begin{array}{l}\text { bukan pula terhadap serangan yang } \\
\text { telah berakhir. } \\
\text { c. Perbutan sebagai perlawanan yang } \\
\text { dilakukan itu harus benar-benar } \\
\text { terpaksa atau dalam keadaan darurat } \\
\text { tidak ada pilihan lain untuk } \\
\text { menghindar dari serangan tersebut. }\end{array}$ \\
\hline 48 & $\begin{array}{l}\text { Keadaan Darurat ( Pasal 48) } \\
\text { 1.Pertentangan antara dua kepentingan } \\
\text { hukum } \\
\text { Contoh: } \\
\text { Ada sebuah kapal yang tengah berlayar. } \\
\text { Tiba - tiba kapal tersebut menabrak } \\
\text { gunung es sehingga kapal tersebut akan } \\
\text { tenggelam. Setiap penumpang ingin } \\
\text { sekali menyelamatkan diri. Semua sekoci } \\
\text { telah dikeluarkan namun tidak dapat } \\
\text { menampung jumlah penumpang hingga } \\
\text { akhirnya ada penumpang yang terpaksa } \\
\text { berpegangan sebuah papan. Papan } \\
\text { tersebut diperebutkan oleh } 2 \text { orang } \\
\text { padahal kekuatannya hanya untuk satu } \\
\text { orang. Salah satu penumpang berfikir jika } \\
\text { papan tersebut tetap dipegangi } 2 \text { orang } \\
\text { maka papan tersebut akan tenggelam } \\
\text { dan keduanya akan mati. Kemudian } \\
\text { penumpang } 1 \text { mendorong yang lainnya } \\
\text { hingga tenggelam dan mati. Penumpang } \\
\text { yang mendorong yang lainnya hingga }\end{array}$ \\
\hline
\end{tabular}




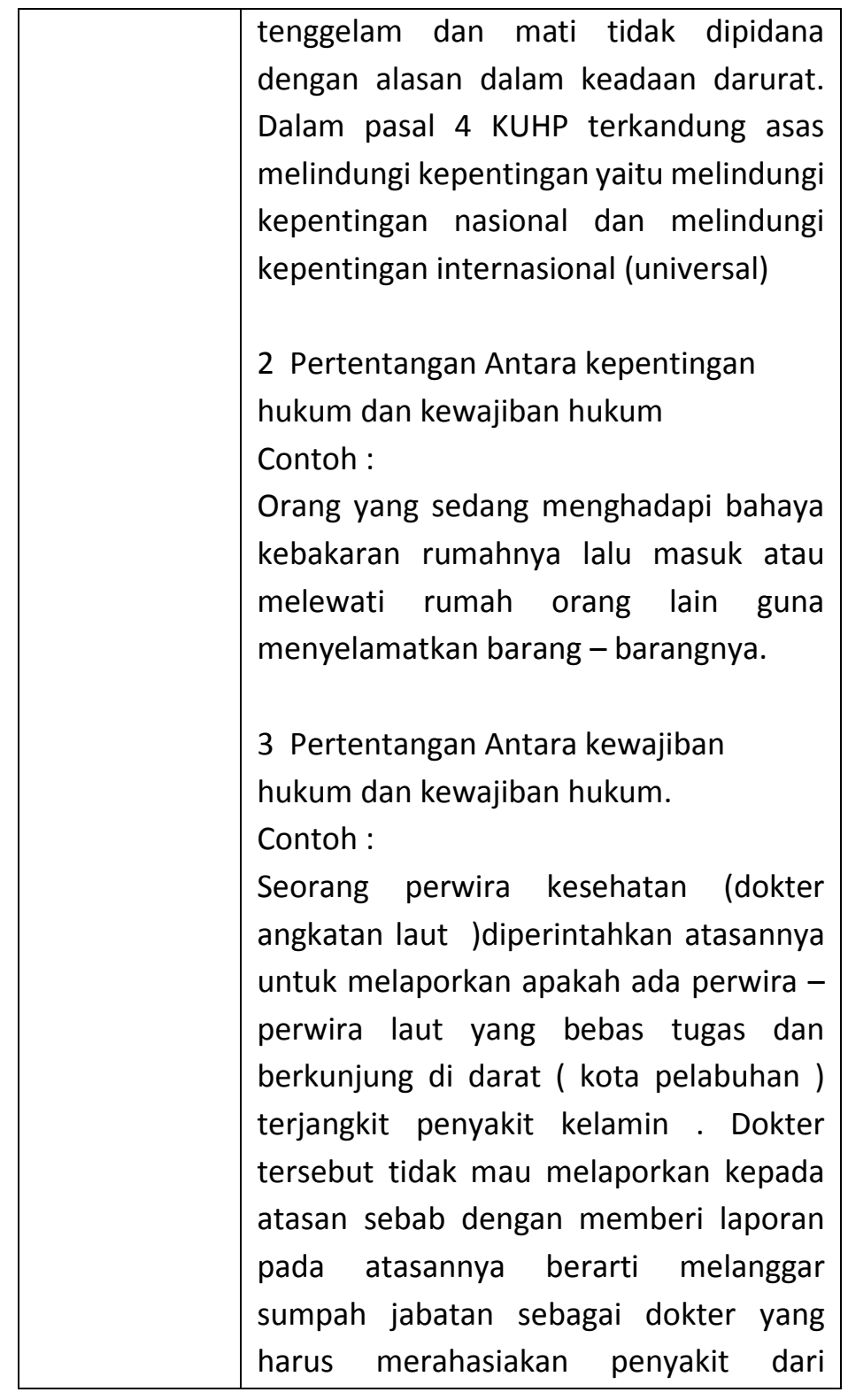




\begin{tabular}{|l|l|}
\hline 51 ayat (1) & $\begin{array}{l}\text { pasiennya. Disini dihadapkan pada dua } \\
\text { kewajiban hukum yaitu melaksanakan } \\
\text { perintah dari atasannya ( sebagai tentara) } \\
\text { dan memegang teguh rahasia jabatan } \\
\text { sebagai dokter. }\end{array}$ \\
$\begin{array}{l}\text { Melaksanakan Peraturan Perundang- } \\
\text { Pasal ini menentukan pada prinsipnya } \\
\text { orang yang melakukan suatu perbuatan, } \\
\text { meskipun itu merupakan tindak pidana, } \\
\text { tetapi karena dilakukan atas perintah } \\
\text { undang-undang, maka pelaku tidak boleh } \\
\text { dihukum. Asalkan perbuatannya tersebut } \\
\text { untuk kepentingan umum bukan untuk } \\
\text { kepentingan pribadi pelaku. Jadi ada } \\
\text { suatu kepentingan yang lebih besar yang } \\
\text { harus diutamakan oleh pelaku. } \\
\text { Kepentingan yang lebih besar, yang lebih } \\
\text { baik ini merupakan alasan pembenar } \\
\text { baginya untuk melakukan perbuatan } \\
\text { tersebut, meskipun perbuatan itu } \\
\text { merupakan perbuatan pidana. }\end{array}$ \\
\hline $\begin{array}{l}\text { Melakukan Perintah Jabatan yang Sah } \\
\text { Pasal ini menghendaki bahwa pelaku } \\
\text { tindak pidana yang perbuatannya } \\
\text { didasarkan atas perintah jabatan atau }\end{array}$ \\
\hline and
\end{tabular}




\begin{tabular}{|l|l|}
\hline pengauasa yang sah tidak bisa dihukum \\
atau tidak boleh dihukum. \\
Yang dimaksud dengan perintah di sini \\
adalah perintah tersebut bisa berupa \\
perintah tertulis maupun intruksi lisan. \\
Yang memerintahkan dan yang \\
diperintah harus ada hubungan (dalam \\
ruang lingkup kewenangan/kekuasaan). \\
\hline
\end{tabular}

\section{SOAL - SOAL LATIHAN .}

1. Jelaskan pengertian tanggungjawab pidana

2. Jelaskan yang dimaksud dengan alasan pemaaf beserta macam- macam alasan pemaaf

3. Jelaskan yang dimaksud dengan alasan pembenar beserta macam - macam alasan pembenar 


\section{REFERENSI}

Ey Kanter dan SR Sianturi, Asas - Asas Hukum Pidana di Indonesia dan Penerapannya, Storia Grafika, Jakarta, 2002

Moelyatno, Asas - Asas Hukum Pidana, Gajahmada University Pess, Yogyakarta, 1980

Lamintang PAF, 1997, Dasar - dasar Hukum Pidana Indonesia, Bandung, Cipta Dutya Bakti,

Prodjodikoro Wiryono,1986, Asas - Asas Hukum Pidana Indonesia, Bandung, PT Eresko, 


\section{BAB VII}

\section{KESENGAJAAN DAN KEALPAAN}

\section{SUB KOMPETENSI}

1. Pendahuluan

2. Kesengajaan

3. kealpaan

\section{TUJUAN PEMBELAJARAN}

Mahasiswa pada akhir pembelajaran di level kompetensi ini mampu memahami dan menjelaskan pengertian kesengajaan, macam macam kesengajaan, pengertian kealpaan dan unsur - unsur kealpaan

\section{INDIKATOR HASIL BELAJAR}

1. Mahasiswa dapat menjelaskan pengertian kesengajaan

2. Mahasiswa dapat menjelaskan macam - macam kesengajaan

3. Mahasiswa dapat menjelaskan pengertian kealpaan

4. Mahasiswa dapat menjelaskan unsur - unsur kealpaan. 


\section{MATERI}

\section{A. Pendahuluan}

Pertanggungjawaban pidana mulai ada karena kesalahan. Kesalahan sendiri dianggap ada, apabila dengan sengaja atau karena kelalaian telah melakukan perbuatan yang menimbulkan keadaan atau akibat yang dilarang oleh hukum pidana dan dilakukan dengan mampu bertanggung jawab.

Kesalahan ditujukan pada perbuatan yang tidak patut, yaitu melakukan sesuatu yang seharusnya tidak dilakukan atau tidak melakukan sesuatu yang seharusnya dilakukan. Menurut ketentuan yang diatur dalam hukum pidana bentuk-bentuk kesalahan terdiri atas :

a. Kesengajaan (opzet)

b. Kelalaian/kealpaan (culpa)

\section{B. Kesengajaan (opzet)}

Kesengajaan harus memenuhi ketiga unsur tindak pidana yaitu (1) perbuatan yang dilarang, (2) akibat yang menjadi pokok alasan diadakannya larangan dan (3) bahwa perbuatan itu melanggar hukum. ${ }^{21}$

Kesengajaan dapat dibagi menjadi tiga bagian :

1. Sengaja sebagai niat (Oogmerk)

Bahwa dengan kesengajaan yang bersifat tujuan (oogmerk) si pelaku dapat dipertanggungjawabkan, mudah dapat dimengerti oleh khalayak ramai. Maka apabila kesengajaan semacam ini ada pasa suatu tindak pidana, tidak ada yang

${ }^{21}$ Wirjono prodjodiro, Op, Cit hal. 61 
menyangkal, bahwa si pelaku pantas dikenakan hukuman pidana ini lebih tampak apabila dikemukakan, dengan adanya kesengajaan yang bersifat tujuan ini, dapat dikatakan si pelaku benar-benar menghendaki mencapai akibat yang menjadi pokok alas an diadakannya hukum pidana (constitutief gevolg).

Kesengajaan ini menggunakan teori kehendak. Bahwa yang dapat dikehendaki adalah perbuatannya bukan akibatnya.

\section{Contoh :}

A menghendaki kematian $B$. Oleh sebab itu A mengarahkan pistolnya kepada B. selanjutnya ia menembak mati B. akibat penembakan yaitu kematian $B$ adalah benar dikehendaki $A$.

Kesengajaan sebagai niat merupakan bentuk sengaja yang paling sederhana.

2. Sengaja sadar akan kepastian atau keharusan (zekerheidbewustzijn)

Kesengajaan ini apabaila si pelaku dengan perbuatannya tidak bertujuan untuk mencapai akibat yang menjadi dasar dari delik, tetapi ia tahu benar, bahwa akibat itu pasti akan mengikuti perbuatan itu. Teori ini menghendaki kesengajaan tidak hanya dikehendaki saja, tetapi terjadi juga karena ada bayangan yang akan menghadirkan kepastian.

Contoh : 
Agar dapat mencapai tujuannya yaitu membunuh B maka A sebelumnya harus membunuh $C$, karena $C$ menjadi pengawal B. Antara A dan C sebenarnya tidak ada permusuhan. Hanya kebetulan $C$ pengawal $B, A$ terpaksa sengaja terlebih dahulu membunuh $C$ kemudian membunuh $B$. Pembunuhan $B$ berarti maksud $A$ tercapai. A yakin bahwa ia hanya dapat membunuh B setelah terlebih dahulu membunuh C, walaupun pembunuhan $C$ itu pada permulaannya tidak dimaksudkannya. A yakin bahwa jika ia tidak terlebih dahulu membunuh $\mathrm{C}$ maka tentu ia tidak pernah akan dapat membunuh $B$.

Menurut Van Hattum "Kepastian" dalam kesengajaan semacam ini harus diartikan secara relative oleh karena secara ilm pasti tidak mungkin ada kepastian mutlak. Kepastian itu sendiri adalah suatu kemungkinan yang sangat besar sedemikian rupa, bahwa seorang manusia biasa menganggap ada kepastian, tidak ada kemungkinan besar itu.

3. Sengaja sadar akan kemungkinan (dolus eventualis mogelijkeheidbewustzijn)

Kesengajaan ini hanya didasarkan pada kemungkinan belaka akan akibat, tidak didasarkan pada kepatian dan/atau kepastian suatu bayangan.

Contoh :

A hendak membalas dendam terhadap B. A mengirimkan sebuah kue tart ke alamat B. Dalam tart tersebut telah dimasuki racun. A sadar akan kemungkinan besar bahwa istri 
B turut serta makan kue tart tersebut. Walaupun ia tahu tetapi ia tidak menghiraukan. Oleh hakim ditentukan bahwa perbuatan A terhadap istri B dilakukan dengan sengaja yaitu sengaja sadar akan kemungkinan.

Rumusan unsur sengaja terdapat beberapa istilah yang digunakan :

1. Dengan sengaja, antara lain dalam rumusan pasal $333 \mathrm{KUHP}$, pasal 338 KUHP, pasal 372 KUHP dan sebagainya.

Pasal 333 ayat (1) KUHP :

"Barangsiapa dengan sengaja melawan hukummerampas kemerdekaan seseorang, atau meneruskan perampasan kemerdekaan yang demikian, diancam dengan pidana penjara paling lama delapan tahun".

\section{Pasal 338 KUHP :}

"Barangsiapa dengan sengaja merampas nyawa orang lain, diancam karena pembunuhan dengan pidana paling lama lima belas tahun".

Pasal 372 KUHP :

"Barangsiapa dengan sengaja dan melawan hukum memiliki barang sesuatu yang seluruhnya atau sebagian adalah kepunyaan orang lain, tetapi yang ada dalam kekuasaannya bukan karena kejahatan diancam karena penggelapan dengan pidana paling lama empat tahun atau pidana denda paling banyak Sembilan ratus rupiah"

2. Sedang ia mengetahui, sebagaimana terdapat pada pasal 204,220,279 KUHP 


\section{Pasal 204 KUHP}

"Barangsiapa memberitahukan atau mengadukan bahwa telah dilakukan suatu perbuatan pidana, padahal mengetahui bahwa itu tidak dilakukan, diancam dengan pidana penjara paling lama satu tahun empat bulan".

\section{Pasal 279 KUHP}

(1) Diancam dengan pidana penjara paling lama lima tahun

1. Barangsiapa mengadakan perkawinan padahal mengetahui bahwa perkawinan atau perkawinan - perkawinannya yang telah ada menjadi penghalang yang sah untuk itu.

2. Barangsiapa mengadakan perkawinan padahal mengetahui bahwa perkawinan atau perkawinan - perkawinan pihak lain menjadi penghalang untuk itu.

3. Yang ia ketahui, seperti yang dirumuskan dalam pasal 480 KUHP

Pasal 480 KUHP :

"Diancam dengan pidana penjara paling lama empat tahun atau pidana denda paling banyak Sembilan ratus rupiah;

1. Barangsiapa membeli, menyewa, menukar, menerima gadai, menerima hadiah, atau untuk menarik keuntungan, menjual, menyewakan, menukarkan, menggadai, mengangkut, menyimpan atau menyembunyikan sesuatu benda yang diketahui atau 
sepatutnya harus diduga bahwa diperoleh dari kejahatan penadahan.

2. Barangsiapa menarik keuntungan dari hasil sesuatu benda, yang diketahuinya atau sepatutnya harus diduga bahwa diperoleh dari kejahatan.

4. Dengan tujuan, sebagaimana dirumuskan dalam pasal 362 KUHP

Pasal 362 KUHP

"Barangsiapa mengambil barang sesuatu, yang seluruhnya atau sebagian kepunyaan orang lain, dengan maksud untuk dimiliki secara melawan hukum, diancam karena pencurian dengan pidana penjara paling lama lima tahun, atau pidana denda paling banyak Sembilan ratus rupiah".

5. Bertentangan dengan apa yang yang diketahui, sebagaimana dirumuskan dalam pasal 311 KUHP

Pasal 311 KUHP :

(1) Jika yang melakukan kejahatan pencemaran atau pencemaran tertulis dibolehkan untuk membuktikan apa yang dituduhkan itu benar, tidak membuktikannya, dan tuduhan dilakukan bertentangan dengan apa yang diketahui, maka dia diancam melakukan fitnah dengan pidana penjara paling lama empat tahun.

6. Dengan tujuan yang ia ketahui, sebagaimana dirumuskan dalam pasal 310 KUHP. 


\section{Kealpaan (Culpa)}

Kelalaian merupakan salah satu bentuk kesalahan yang timbul karena pelakunya tidak memenuhi standar perilaku yang telah ditentukan menurut undang-undang. Disamping itu, kelalaian itu terjadi karena perilku orang itu sendiri.

Kelalaian atau kealpaan dalam hukum pidana dibagi menjadi dua macam yaitu :

1. Kealpaan perbuatan, apabila hanya dengan melakukan perbuatannya sudah merupakan suatu peristiwa pidana, maka tidak perlu mellihat akibat yang timbul dari perbuatan tersebut sebagaimana ketentuan Pasal 205 KUHP.

2. Kealpaan akibat, merupakan suatu peristiwa pidana kalau akibat dari kealpaan itu sendiri sudah menimbulkan akibat yang dilarang oleh hukum pidana, misalnya cacat atau matinta orang lain sebagaimana yang diatur dalam Pasal 359, 360361 KUHP.

Kealpaan itu memuat tiga unsur yaitu :

1. Pelaku berbuat lain dari apa yang seharusnya diperbuat menurut hukum tertulis maupun tidak tertulis, sehingga sebenarnya ia telah melakukan suatu perbuatan (termasuk tidak berbuat) yang melawan hukum.

2. Pelaku telah berlaku kurang berhati hati, ceroboh dan kurang berpikir panjang.

3. Perbuatan pelaku itu dapat dicela, oleh karenaya pelaku harus bertanggung jawab atas akibat dari perbuatannya tersebut. 
Menurut D. Schaffmeister, N. Keijzer dan E. PH Sutorius, kealpaan ada dua skema yaitu :

1. Culpa lata yang disadari (alpa)

Concious : kelalaian yang disadari, contohnya antara lain sembrono (roekeloos), lalai (onachttzaam), tidak acuh. Di mana seseorang sadar akan risiko, tetapi berharap akibat buruk tidak ada kan terjadi.

2. Culpa lata yang tidak disadari (lalai)

Unconsius: kelalaian yang tidak didasari contohnya antara lain kurang berpikir (onnadentkend), lengah (onoplettend), di mana seseorang seharusnya sadar dengan risiko, tetapi tidak demikian.

Sehingga kelalaian yang disadari terjadi apabila seseorang tidak melakuan suatu perbuatan, namun dia sadar apabila dia tidak melakukan perbuatan tersbeut maka akan timbul akibat yang dilarang dalam hukum pidana. Sedangkan kelalaian yang tidak disadari terjadi apabila pelaku tidak memikirkan kemungkinan adanya suatu akibat atau keadaan tertentu, dan apabila ia telah memikirkan hal itu sebelumnya maka ia tidak akan melakukannya.

Pada kealpaan tetap dimungkinkan adanya pemidanaan walaupun ancaman pidananya jauh lebih ringan daripada kesengajaan. Karena pada kealpaan ada keadaan sedemikian yang membahayakan keamanan orang atau barang. Disamping itu kealpaan mendatangkan kerugian yang besar bagi orang lain 
sehingga tidak dapat diperbaiki lagi sebagai akibat dari kekuranghati - hatian atau semrono tersebut. ${ }^{22}$

Ancaman pidana kealpaan lebih ringan di banding tindak pidana yang memuat unsur kesengajaan. Berikut contoh pasal yang dilakukan dengan kesengajaan dan dilakukan dengan kealpaan :

Pasal 200 KUHP :

"Barangsiapa dengan sengaja menghancurkan atau merusak gedung atau bangunan diancam :

(1) Dengan pidana penjara paling lama 12 tahun, jika perbuatan itu timbul bahaya umum bagi barang

(2) Dengan pidana penjarapaling lama dua belas tahun, jika karena perbuatan itu timbul bahaya bagi nyawa orang lain.

(3) Dengan pidana seumur hidup atau pidana penjara selama waktu tertentu paling lama duapuluh tahun, jika karena perbuatan itu timbul bahaya bagi nyawa orang lain dan mengakibatkan orang mati.

Pasal 201 KUHP :

"Barangsiapa karena kesalahannya (kealpaannya) menyebabkan gedung atau bangunan hancur atau rusak diancam :

1. Dengan pidana penjara paling lama empat bulan dua minggu atau pidana kurungan paling lama tiga bulan atau pidana

22 Masruchin Ruba'l Buku Ajar Hukum Pidana, Media Nusa Creative, Malang 2015 hal 111. 
denda paling banyak empat ribu lima ratus rupiah, jika perbuatan itu menimbulkan bahaya umum bagi orang.

2. Dengan pidana penjara paling lama Sembilan bulan atau pidana kurungan paling lama enam bulan atau pidana denda paling banyak empat ribu lima ratus rupiah, jika perbuatan itu menimbulkan bahaya bagi nyawa orang.

3. Dengan pidana penjara paling lama satu tahun empat bulan atau pidana kurungan paling lama satu tahun jika perbuatan itu mengakibatkan orang mati.

Dua pasal diatas dapat disimpulkan bahwa :

1. Pasal 200 menyebutkan perbuatan pidana dengan sengaja sedangkan pasal 201 adalah perbuatan pidana karena kealpaan

2. Perbuatan pidana yang disengaja maupun karena lalai, alpa dapat dipidana

3. Hukuman bagi kealpaan lebih ringan disbanding kesengajaan.

\section{SOAL - SOAL LATIHAN}

1. Jelaskan pengertian kesengajaan

2. Sebutkan dan uraikan macam - macam kesengajaan

3. Jelaskan pengertian kealpaan

4. Sebutkan unsur - unsur kealpaan.

\section{REFERENSI}

Masruchin Ruba'I dkk, Buku Ajar Hukum Pidana, Media Nusa Creative, Malang, 2015. 


\section{BAB VIII \\ PERCOBAAN}

SUB KOMPETENSI

1. Pengertian Percobaan

2. Jenis - jenis Percobaan

TUJUAN PEMBELAJARAN 
Mahasiswa pada akhir pembelajaran di level kompetensi ini mampu memahami dan menjelaskan pengertian percobaan, jenis - jenis percobaan beserta contohnya dan dan sanksi pidana terhadap percobaan.

\section{INDIKATOR HASIL BELAJAR}

1. Mahasiswa dapat menjelaskan pengertian percobaan

2. Mahasiswa dapat menjelaskan jenis - jenis percobaan beserta contohnya

3. Mahasiswa dapat menjelaskan sanksi pidana terhadap percobaan.

\section{MATERI}

\section{Pengertian Percobaan (Pooging)}

KUHP tidak mengenal pengertian percobaan tetapi hanya dirumuskan batas kapan suatu percobaan melakukan tindak pidana dapat dilakukan pemidanaan. Percobaan diatur dalam pasal 53 dan 54 KUHP. Pasal 53 merumuskan sebagai beikut :

(1) mencoba melakukan kejahatan dipidana, jika niat untuk telah ternyata dari adanya permulaan pelaksanaan dan tidak selesainya pelaksanaan itu bukan semata-mata disebabkan karena kehendaknya sendiri.

(2) Maksimum pidana pokok terhadap kejahatan dalam percobaan dikurangi sepertiga

(3) Jika kejahatan diancam dengan pidana mati atau pidana seumur hidup, dijatuhkan pidana penjara paling lama lima belas tahun.

(4) Pidana tambahan bagi percobaan sama dengan kejahatan selesai. 
Pasal 54

"Mencoba melakukan pelanggaran tidak dipidana".

Sistem KUHP merumuskan bahwa tidak semua percobaan dapat dipidana. Yang dapat dipidana hanya yang berupa kejahatan saja, sedangkan pelanggaran tidak dapat dipidana. Begitu pula tidak semua percobaan kejahatan dapat dipidana. Ada percobaan kejahatan-kejahatan tertentu yang tidak dapat dipidana, contohnya percobaan duel/perkelaian tanding, percobaan penganiayaan riangan terhadap hewan, Percobaan penganiayaan biasa, dan percobaan penganiayaan ringan .

Dari unsure tersebut diatas, maka dapat dikonsepkan bahwa syarat untuk dapat dipidananya percobaan adalah sebagai berikut :

1. Adanya perbuatan permulaan

2. Perbuatan tersebut tidak selesai atau tujuan tidak tercapai.

3. Tidak selesainya perbuatan tersebut bukan kehendak sendiri

1. Adanya niat

Adanya niat menurut doktrin adalah adanya kehendak untuk melakukan kejahatan. Atau lebih tepatnya disebut opzet atau kesengajaan.

2. Adanya permulaan pelaksanaan

Niat adalah keinginan yang berada dalam batin seseorang. Karena masih ada dalam batin maka sulitlah untuk diketahui. Niat bisa diketahui apabila disampaikan kepada orang lain. Niat atau kehendak belum cukup bagi seseorang untuk dapat dipidana. 
Adanya perbuatan permulaan berguna untuk menentukan apakah percobaan untuk melaksanakan kejahatan sudah ada atau belum.

3. Tidak selesainya perbuatan tersebut bukan karena kehendak sendiri.

Jadi apabila tindak pidana tersebut tidak selesai karena kehendaknya sendiri maka belum dimaksud dengan percobaan.

\section{Jenis - Jenis Percobaan}

1. Percobaan selesai atau percobaan lengkap.

Adalah suatu percobaan apabila si pembuat telah melakukan kesengajaan untuk menyelesaikan suatu tindak pidana tetapi tidak terwujud bukan atas kehendaknya.

Contoh : - A menembak B tetapi meleset.

Contoh diatas menggambarkan perbuatannya diselesaikan dengan lengkap.

2. Percobaan tertunda atau percobaan terhenti atau tidak lengkap

Adalah suatu percobaan apabila tindak pidana dilakukan tetapi karena satu hal maka yang dilakukan tidak selesai.

Contoh : A membidikkan pistolnya ke B dan dihalangi oleh C

Contoh diatas menggambarkan perbuatannya belum terlaksana dengan lengkap. Akan tetapi niat, permulaan pelaksanaan dan pelaksanaannya sudah dilakukan.

3. Percobaan tidak mampu 
Adalah suatu percobaan yang sejak dimulai telah dapat dikatakan tidak mungkin untuk menimbulkan tindak pidana selesai karena :

- $\quad$ Alat yang dipakai untuk melakukan tindak pidana adalah tidak mampu/tidak sesuai.

Contoh : Menembak seseorang akan tetapi memakai peluru timah panas. padahal diketahuinya bahwa timah panas tidak mematikan seseorang akan tetapi hanya melumpuhkan.

- Obyeknya yang tidak mampu

Contoh :

Seseorang yang akan mencuri akan tetapi obyek yang akan dicuri terlalu berat, sehingga tidak kuat mengangkatnya dan pencurianpun gagal dilakukan.

Dikatakan percobaan yang mampu apabila perbuatan dan alat yang dipakainya menurut sifatnya mampu untuk menimbulkan delik yang dituju. Sedangkan disebut percobaan yang tidak mampu apabila memang tidak menimbulkan delik yang dituju. Ketidakmampuan tersebut disebabkan oleh alat atau obyeknya.

\section{Sanksi pidana}

Sanksi untuk percobaan berbeda dengan delik yang sempurna. Menurut pasal 53 (2) KUHP dalam hal percobaan terhadap kejahatan maka pidana yang dapat dijatuhkan adalah maksimal pidana kejahatan yang bersangkutan dikurangi sepertiga. Misalnya percobaan pembunuhan (pasal 53 jo 338 KUHP) maka maksimum pemidanaannya adalah 10 tahun penjara. Apabila kejahatan diancam 
pidana mati atau pidana seumur hidup maka ( misalnya pembunuhan berencana ( pasal 340 KUHP ) menurut pasal 53 (3) maksimum pidana yang dapat dijatuhkan adalah 15 tahun penjara. Dari uraian tersebut diatas maka dapat ditarik kesimpulan bahwa penjatuhan pidana dalam percobaan lebih rendah dibanding kejahatan yang dilakukan selesai seluruhnya. Sedangkan untuk pidana tambahan adalah sama dengan kejahatan selesai sebagaimana diatur dalam pasal 53 (4) KUHP.

\section{SOAL - SOAL LATIHAN}

1. Jelaskan pengertian percobaan

2. Sebutkan jenis - jenis percobaan beserta contohnya

3. Jelaskan sanksi pidana percobaan

\section{REFERENSI}

Adami Chazawi, Pelajaran Hukum Pidana 3 Percobaan dan Penyertaan, Raja Grafindo Persada, Jakarta, 2002

E.Y Kanter dan S.R Sianturi, asas - Asas Hukum Pidana Indonesia dan Penerapannya, Alumni-PHTM, Jakarta 1982 


\section{BAB IX \\ RESIDIVE}

\section{SUB KOMPETENSI}

1. Pengertian residive

2. Jenis - jenis residive

\section{TUJUAN PEMBELAJARAN}

Mahasiswa pada akhir pembelajaran di level kompetensi ini mampu memahami dan menjelaskan pengertian residive dan menyebutkan jenis - jenis residive.

\section{INDIKATOR HASIL BELAJAR}

1. Mahasiswa dapat menjelaskan pengertian residive

2. Mahasiswa dapat menyebutkan jenis - jenis residive 


\section{MATERI}

\section{Pengertian Residive}

Residive sama dengan penggulangan. Sehingga Residive dalam ilmu hukum pidana adalah pengulangan tindak pidana dan telah dijatuhi pidana dengan suatu putusan pengadilan yang telah memiliki kekuatan hukum tetap (in krachtvan gewijsde), kemudian yang bersangkutan melakukan tindak pidana lagi. Jadi dalam residive ini sama halnya dengan concursus realis, seseorang melakukan lebih dari satu tindak pidana. Perbedaanya kalau dalam residive salah satu tindak pidana sudah memiliki kekuatan hukum yang tetap.

Recidive ini terjadi jika orang yang sama telah dinyatakan bersalah karena melakukan satu atau beberapa perbuatan pidana, kemudian mengulangi melakukan perbuatan pidana dimana antara kasus yang satu dengan yang lain dipisahkan oleh putusan yang telah memiliki kekuatan hukum tetap.

Pembuat undang - undang memiliki dasar pemikiran bahwa pelaku resive memiliki kebiasaan yang jahat dianggap berbahaya dan mengganggu kepentingan umum.

Syarat - syarat dikategorikan residive :

1. Harus pernah dihukum terhadap kejahatan pertama yang pernah dilaukan.

2. Keputusan hakim harus bersifat tetap

3. Adanya jangka waktu antara kejahatan yang diulangi kemudian ( kejahatan ke 2 ) dan hukuman yang telah dijatuhkan terhadap kejahatan pertama dalam jangka waktu 5 tahun.

Dalam praktiknya penerapan residive ini masih minim sekali, karena mengandung beberapa problem. Selama ini putusan yang telah 
memiliki kekuatan hukum tetap hanya menjadi pertimbangan yang memberatkan saja.

Menurut pandangan Van Hamel, terdapat suatu konsekuensi dari terjadinya suatu penggulangan tindak pidana. ${ }^{23}$ Konsekwensi pertama, setiap penjatuhan hukuman akan menyebabkan adanya suatu pemberatan hukum tanpa adany.a suatu ketentuan bahwa perbuatan yang harus terjadi harus sama dengan perbuatan yang dihukum. Kedua, disyaratkan adanya suatu kesamaan tindak pidana antara perbuatan-perbuatan yang dapat dihukum yang pernah terjadi.

\section{Jenis - Jenis Residive}

Secara sederhana residive dapat dibedakan menjadi dua yaitu :

1. Penggulangan tindak pidana yang bersifat umum (algemeneine recidive).

2. Penggulangan yang bersifat khusus (byzondere recidive).

Penggolongan residive menurut Doktrin (Pendapat Ahli) :

a. Residive umum

Sistem ini menyatakan "setiap pengulangan terhadap jenis tindak pidana apa pun dan dilakukan dalam waktu kapan saja, merupakan alas an untuk pemberatan pidana". Jadi tidak ditentukan jenis tindak pidana yang dilakukan maupun tenggang waktu penggulangannya. Dengan tidak ditentukannya tenggang waktu maka sistem ini tidak mengenal daluwarsa.

b. Residive khusus

${ }^{23}$ Van Hamel, dikutip Simons dan Lamintang, hal 493 
Sistem ini merumuskan bahwa tidak setiap pengulangan tindak pidana sebagai alasan untuk memperberat pidana. Pidana diperberat hanya terhadap tindak pidana yang sudah ditentukan dan dalam waktu tertentu sebagaimana diatur dalam undang - undang.

Penggolongan Risidive Menurut KUHP:

Konsep kUHP menerapakan sistem residive khusus. Artinya pemberatan pidana hanya dikenakan pada penggulangan jenisjenis tindak pidana (kejahatan/pelanggaran) tertentu saja dan yang dilakukan dalam tenggang waktu tertentu. Sebagai penggambaran pada tabel di bawah ini :

\section{SOAL - SOAL LATIHAN}

1. Jelaskan pengertian residive

2. Sebutkan jenis - jenis residive serta berikan penjelasannya. 


\section{BAB $X$ \\ GUGURNYA KEWENANGAN MENUNTUT \\ DAN MENJALANKAN PIDANA.}

\section{SUB KOMPETENSI}

1. Gugurnya kewenangan menuntut

2. Gugurnya kewenangan menjalankan Pidana

\section{TUJUAN PEMBELAJARAN}

Mahasiswa pada akhir pembelajaran di level kompetensi ini mampu memahami dan menjelaskan alasan gugurnya kewenangan menuntut dan alasan gugurnya kewenangan menjalankan pidana.

INDIKATOR HASIL BELAJAR

1. Mahasiswa dapat menjelaskan alasan gugurnya kewenangan menuntut

2. Mahasiswa dapat menjelaskan alasan gugurnya menjalankan pidana

\section{MATERI}

C. Gugurnya Kewenangan Menuntut 
Semua tindak pidana yang dilakukan oleh subyek hukum pidana harus dituntut di muka siding pengadilan sebagai pelaksanaan prinsip persamaan di depan hukum. Akan tetapi dalam beberapa hal undang-undang menentukan alasan gugurnya hak menuntut sehingga pelaku tidak dituntut atau dimintai pertanggungjawaban pidana.

Alasan-alasan ini disebut dengan alasan gugurnya hak menuntut.

Di dalam KUHP diatur dalam Bab VIII Buku 1 KUHP dan di undangundang di luar KUHP.

Alasan-alasan tersebut diantaranya adalah sebagai berikut :

1. Ne bis idem

2. Matinya terdakwa

3. Daluwarsa

4. Telah ada pembayaran denda maksimum kepada pejabat tertentu untuk pelanggaran yang hanya diancam dengan dena saja

5. Abolisi atau amnesti (di luar KUHP).

\section{Ad. 1 Ne Bis In Idem}

Ne bis in idem disebut juga dengan non bis in idem yang artinya tidak melakukan pemeriksaan untuk kedua kalinya mengenai perbuatan yang sama. Ketentuan ini didasarkan pada pertimbangan bahwa suatu saat harus ada akhir dari pemeriksaan/penuntutan dan akhir dari berlakuknya ketentuan pidana terhadap suatu delik tertentu.

Asas ini menjadi pegangan agar tidak ada pemeriksaan lagi atas kasus yang sama. Barda Nawawi Arief mengartikan nebis in idem 
adalah "tidak atau jangan dua kali yang sama". Dasar dari pemikiran atau ratio dari asas ini adalah : ${ }^{24}$

a. Untuk menjaga martabat pengadilan (untuk tidak memerosotkan kewajiban Negara) b. Untuk rasa kepastian bagi terdakwa yang telah mendapatkan keputusan.

Di dalam KUHP asas ini dirumuskan dalam Pasal 76 ayat (1) Ke-1 KUHP. Adapaun syarat agar penuntutan terhadap seseorang dapat hapus berdasarkan nebis in idem adalah sebagai berikut :

1. Sudah ada putusan hakim yang mempunyai kekuatan hukum tetap.

2. Putusan hakim yang sudah berkekuatan hukum tetap dilakukan oleh orang yang sama

3. Perbuatan pidana yang sudah diputus dan berkekuatan hukum tetap dan dijalankan sama dengan perbuatan pidana yang dilakukan untuk kedua kalinya.

\section{Ad. 2. Meninggalnya Terdakwa (Pasal 77 KUHP)}

Prinsip pertanggungjawaban pidana adalah pribadi tidak dapat diwakili atau dialihkan kepada orang lain. Sehingga ketika yang bersangkutan meninggal dunia, maka dengan sendirinya gugur hak untuk menuntut.

\section{Ad. 3 Daluwarsa Penuntutan}

KUHP merumuskan daluwarsa suatu kasus pidana, sebagaimana Pasal 78 ayat (1) KUHP. Sehingga apabila kualifikasi daluwarsa tersebut terpenuhi, maka dengan sendirinya gugur hak untuk menuntut.

\footnotetext{
${ }^{24}$ E.Y Kanter dan SR Slanturi, Asas-asas Hukum Pidana di Indonesia dan Penerapannya, Storia Grafika, Jakarta 202, hal. 427.
} 
Konsep daluwarsa dalam Pasal 78 ayat (1) adalah sebagai berikut

a. Pelanggaran dan kejahatan percetakan masa daluwarsa setelah satu tahun

b. Kejahatan yang dikenakan ancaman hukuman denda, kurungan atau penjara tiga tahun masa daluwarsanya sesudah enam tahun

c. Kejahatan yang dikenakan ancaman hukuman penjara lebih dari tiga tahun masa daluwarsanya sesudah duabelas tahun

d. Kejahatan yang dikenakan ancaman hukuman mati atau seumur hidup masa daluwarsanya delapanbelas tahun.

Sedangkan rumusan tersebut di atas akan berbeda untuk anakanak (dibawah sama dengan 18 Tahun) dikurangi sepertiga sebagaimana Ketentuan Pasal 78 ayat (2) KUHP.

\section{Ad. 4 Telah ada Pembayaran Maksimum untuk Pelanggaran yang Hanya Diancam dengan Denda (Pasal 82 KUHP)}

Pasal 82 KUHP merumuskan sebagai berikut :

(1) Hak menuntut pidana karena pelanggaran, yang atasnya tidak ditentukan pidana pokok lain daripada denda, hilang jika maksimum denda dibayar dengan rela hati dan demikian juga dibayar biaya perkara, kalau penuntutan telah dilakukan, dengan izin pegawai negeri yang ditunjuk dalam peraturan umum, dalam waktu ditetapkannya. 
(2) Kalau perbuatan itu diancam dengan pidana denda dan rampasan, maka haruslah juga diserahkan barang yang dapat dirampas itu mau dibayar harganya, yang ditaksir oleh pegawai negeri yang tersebut pada ayat pertama.

(3) Dalam hal pidana ditambah karena pengulangan dapat pula penambahan itu dilakukan kalau hak menuntut pelanggaran yang dilakukan dahulu telah hilang menurut ayat pertama dan kedua pasal ini.

(4) Ketentuan Pasal ini tidak berlaku bagi yang belum dewasa, yang umurnya sebelum melakukan perbuatan itu belum cukup enam belas tahun.

Pasal 82 KUHP ini disebut juga dengan afkoop (penebusan) atau sering juga disebut schiking (perdamaian).

\section{Ad. 5 Abolisi dan Amnesti}

a. Amnesti adalah suatu pernyataan terhadap seseorang/orang banyak yang terlibat dalam suatu tindak pidana untuk meniadakan suatu akibat hukum pidana yang timbl dari tindak pidana tersebut.

Seseorang yang harus pernah mendapatkan Drs. Haji Andi Mappetahang Fatwa (AM Fatwa). Beliau mendapatkan amnesty dengan Keputusan Presiden RI No. 127 Tahun 1998.

b. Abolisi adalah penghapusan atau pembasmian tindak pidana. 


\section{Gugurnya Kewenangan Menjalankan Pidana}

Hapusnya pelaksanaan pidana ditentukan sebagai berikut:

1. Terpidana meninggal dunia (Pasal 83 KUHP)

2. Daluwarsa menjalankan hukuman, yaitu :

a. Mengenai semua pelanggaran adalah 2 tahun

b. Mengenai kejahatan yang dilakukan dengan percetakan adalah 5 tahun

c. Mengenai kejahatan yang diancam dengan denda, kurungan atau pidana penjara paling lama tiga tahun adalah 8 tahun.

d. Mengenai kejahatan yang diancam dengan pidana penjara lebih dari tiga tahun adalah 16 tahun. Dengan catatan, apabila dijatuhi pidana lebih dari 16 tahun maka tenggang waktu daluwarsa minimal sama dengan lamanya pidana yang dijatuhkan (Pasal 84 ayat (3) KUHP).

e. Mengenai kejahatan-kejahatan yang diancam dengan pidana mati atau pidana seumur hidupm berdasarkan Pasal 84 ayat (3) KUHP sudah dapat diketahui bahwa tidak mungkin daluwarsa. Hal ini dipertegas lagi dalam Pasal 84 ayat (4) KUHP yang menentukan "kewenangan/hak untuk pelaksanaan pidana mati tidak mungkin daluwarsa".

3. Amnesti dengan pengertian apabila dalam rangka amenesti tersebut telah dijatuhi pidana oleh hakim.

4. Grasi adalah kewenangan kepala Negara untuk memberikan pengampunan terhadap hukuman yang telah dijatuhkan oleh hakim, berupa menghapus seluruhnya, sebagian atau mengubah sifat/bentuk hukuman itu. 
Grasi bukan berarti meniadakan putusan hakim yang sudah berkekuatan hukum tetap. Putusan hakim tetap ada akan tetapi dapat dihapus atau diringankan.

Gasi Presiden dapat berupa :

1. Putusan tidak dieksekusi untuk seluruhnya

2. Putusan dieksekusi hanya sebagian

3. Mengganti jenis pidana. Misalnya pidana penjara diganti dengan pidana kurungan, pidana kurungan diganti dengan pidana denda, pidana mati diganti dengan pidana seumur hidup.

\section{SOAL - SOAL LATIHAN}

1. Sebutkan dan jelaskan alasan gugurnya kewenangan menuntut

2. Sebutkan dan jelaskan alasan gugurnya kewenangan menjalankan pidana

\section{REFERENSI}

E.Y Kanter dan S.R Sianturi, Asas - asas Hukum Pidana di Indonesia dan Penerapannya, Alumni-PHTM, Jakarta, 1982 


\section{BAB XI \\ PENAFSIRAN DALAM HUKUM PIDANA}

\section{SUB KOMPETENSI}

1. Pengertian penafsiran 
2. Macam - macam penafsiran dalam Hukum Pidana

\section{TUJUAN PEMBELAJARAN}

Mahasiswa pada akhir pembelajaran di level kompetensi ini mampu memahami dan menjelaskan pengertian penafsiran dan menyebutkan macam - macam penafsiran dalam hokum pidana.

\section{INDIKATOR HASIL BELAJAR}

1. Mahasiswa dapat menjelaskan pengertian penafsiran

2. Mahasiswa dapat menjelaskan macam - macam penafsiran dalam hukum pidana

\section{MATERI}

\section{Pengertian Penafsiran}

Tujuan menafsirkan undang - undang dalam hokum pidana adalah untuk menentukan arti sebenarnya dari kehendak pembentuk undang - undang sebagaimana tertulis dalam rumusan ketentuan pidana dalam undang - undang tersebut.

Penafsiran hukum (legal interpretation) dalam kajian ilmu hukum dipergunakan dalam hal penerapan hukum dan membentuk hukum. Penafsiran hukum atau interpresi adalah menentukan arti atau makna suatu teks atau bunyi suatu pasal berdasarkan pada kaitannya.

Setiap undang - undang tertulis seperti halnya undang - undang pidana memerlukan suatu penafsiran. Penafsiran yang baik dan tepat rumusan dalam undang - undang, akan membuat undang - undang dapat diterapkan secara baik dan memberi manfaat bagi pihak yang 
terkait. Namun sebaliknya penafsiran rumusan undang - undang yang tidak tepat, undang - undang akan diterapkan secara tidak baik dan tepat. Penafsiran yang baik dalam rumusan undang - undang pidana bertujuan meningkatkan penghargaan kepada hak asasi manusia. Oleh sebab itu penegak hukum khususnya para hakim harus memiliki keahlian dalam menafsirkan undang - undang dengan sebaik - baiknya dengan cara yang dibenarkan oleh undang - undang yang bersangkutan.

Penafsiran hukum dilakukan karena seringkali dalam penerapan dan pembentuan hukum dihadapkan pada problem-problem hukum, mulai dari kefakuman atau kekosongan hukum, hukum yang saling bertentangan dan hukum yang kabur.

Dalam kajian hukum pidana penafsiran ini sangat dibutuhksan sekali. Dalam praktik hukum pidana membutuhkan penafsiran karena ada norma yang tidak jelas dan saling bertentangan. Penafsiran hukum dalam kajian hukum pidana dipergunakan sebagai upaya rasional untuk pemberlakukan hukum pidana yang demoratis dan sesuai dengan tujuan dan maksud teori pemidanaan. Dalam hukum pidana ada beberapa penafsiran yang dipergunakan.

Yang tidak diperbolehkan dalam hukum pidana adalah menggunakan penafsiran analogi. Kebanyakan penulis berpendapat bahwa penggunaan metode penafsiran secara analogi dilarang atau bertentangan dengan ketentuan hukum pidana yaitu yang diatur dalam pasal 1 ayat (1) KUHP yaitu tentang asas legalitas. Alasan utama dilarangnya metode penafsiran undang - undang secara analogi adalah agar ketidakpastian hukum bagi masyarakat jangan sampai menjadi terlalu besar. 
Van Hattum berpendapat bahwa penafsiran undang - undang secara analogi terlarang menurut hukum pidana, apabila karena penerapan semacam itu dapat memperluas suatu rumusan delik. Menurut Van Hattum pasal 1 KUHP untuk mencegah para hakim untuk mencari - cari sebuah norma ataupun membuat suatu norma sendiri, untuk kemudian menjatuhkan suatu hukuman terhadap orang yang telah melanggar norma yang dibuatnya padahal pembentuk undang undang sendiri tidak pernah merumuskan norma itudalam suatu peraturan perundang - undangan.

Simon berpendapat bahwa asas yang terkandung dalam pasal 1 KUHP melarang setiap penerapan hukum secara analogis dalam hukum pidana karena penerapan hukum seperti itu dapat membuat suatu perbuatan yang semula tidak dinyatakan secara tegas sebagai suatu perbuatan yang dilarang menurut undang - undang, kemudian menjadi perbuatan yang terlarang dan pelakunya dapat dihukum.

Van Bemmelem berpendapat bahwa alasan yang paling utama tidak memperbolehkan penafsiran analogi dalam hukum pidana adalah akan mendapat adanya suatu ketidakpastian hukum bagi masyarakat menjadi lebih besar. Menurut Van Bemmelem penerapan penafsiran undang - undang secara analogis dalam hukum pidana adalah melanggar ketentuan pidana seperti dirumuskan dalam pasal 1 ayat (1) KUHP.

\section{Macam - Macam Penafsiran dalam Hukum Pidana.}

1. Penafsiran Gramatikal

Penafsiran berdasarkan tata bahasa, yang karena itu hanya mengingat bunyi kata-kata dalam kalimat itu sendiri (penjelasan undang-undang menurut kata-katanya). 
2. Penafsiran Historis atau Sejarah

Meneliti sejarah dari undang-undang yang bersangkutan.

Sejarah ini ada dua itu, sejarah hukum dan sejarah undangundang.

3. Penafsiran Sistematis

Penafsiaran sistematis adalah penafsiran hukum yang dilakukan dengan memberi arti dan makna isi suatu peraturan perundang-undangan berdasarkan tata urutan materi peraturan perundang-undangan, yaitu mulai dari judul, menimbang, mengingat, memutuskan, bunyi pasal-demi pasal, penjelasan umum, dan penjelasan pasal demi pasal. Gabungan dari hasil penafsiran sistematis ini akan member pemahaman tentang hukum yang berlaku bagi bidang kegiatan tertentu.

4. Penfasiran Telologis/Sosiologis

Penafsiran ini berdasarkan maksud atau tujuan dibuatnya undang-undang tersebut.

5. Penafisiran Autentik (Sahih dan Resmi)

Penafsiran sebagaimana dinyatakan secara pasti oleh pembentuk undang-undang, misalnya Pasal 98 KUHP "malam, malam ditafsirkan waktu antara matahari terbenam da matahari terbit". Dan juga Pasal 100 KUHP, tafsir hewan ternak adalah hewan yang berkuku satu, mamah biak dan babi.

6. Penafsiran Ektensis (Luas) 
Penafsiran berdasarkan luasnya arti kata dalam peraturan itu, sehingga suatu perbuatan dapat dikategorikan sebagai tindak pidana, misalnya aliran listrik diartikan sebagai benda atau barang. Akibat hukumnya adalah siapa yang sengaja mengambil aliran listrik secara illegal dapat dikenahkan Pasal 362 KUHP yaitu pencurian.

7. Penafsiran restriktif/penghalusan hukum

Penafsiran dengan membatasi (mempersempit) arti kata dalam undang-undang itu. Misalnya dalam KUHP dikenal kerugian, kerugian yang dimaksud adalah sakit, cacat dan sebagainya.

8. Penafsiran a Contrario

Menafsirkan undang-undang yang didasarkan pada perlawanan pengertian antara soal yang dihadapi dan soal yang diatur dalam undang-undang. Misalnya Jaksa Penuntut Umum di dalam KUHAP tidak dilarang mengajukan kasasi, sehingga atas putusan bebas murni Jaksa Penuntut Umum mengajukan Kasasi.

9. Penafsiran Perbandingan

Penfasiran komparatif dengan cara membandingkan penjelasan-penjelasan agar ditemukan kejelasan suatu ketentuan undang-undang. Misalnya ajaran melawan hukum dalam tindak pidana korupsi, apakah sama dengan ajaran melawan hukum dalam KUHP?.

\section{SOAL - SOAL LATIHAN}

1. Jelaskan pengertian penafsiran 
2. Sebutkan dan jelaskan macam - macam penafsiran dalam hukum pidana.

\section{BAB XII \\ HUBUNGAN SEBAB AKIBAT \\ TEORI KAUSALITAS}

\section{SUB BAHASAN}

1. Teori Kausalitas

2. Macam - macam teori kausalitas

3. Kausalitas dalam hal tidak berbuat

\section{TUJUAN PEMBELAJARAN}

Mahasiswa pada akhir pembelajaran di level kompetensi ini mampu memahami tentang ajaran kausalitas, menjelaskan teori kausalitas dan koneksitas dalam hal tidak berbuat. 


\section{INDIKATOR HASIL BELAJAR}

1. Mahasiswa mampu menjelaskan tentang ajaran kausalitas

2. Mahasiswa mampu menjelaskan secara detail tentang macam - macam teori kausalitas

3. Mahasiswa dapat memahami tentang kausalitas dalam hal tidak berbuat.

\section{MATERI}

\section{A TEORI KAUSALITAS}

Ajaran Kausalitas adalah ajaran yang mempermasalahkan hingga seberapa jauh suatu tindakan itu dapat dipandang sebagai penyebab dari suatu keadaan, atau hingga berapa jauh suatu keadaan itu dapat dipandang sebagai suatu 1 akibat dari suatu tindakan, dan sampai dimana seseorang yang telah melakukan tindakan tersebut dapat diminta pertanggung jawabannya menurut hukum pidana. IImu pengetahuan hukum pidana mengenal beberapa jenis delik yang penting dalam ajaran kausalitas adalah perbedaan antara delik formal dan delik material. Yang dimaksud dengan delik formal adalah delik yang dianggap selesai dengan di lakukan suatu perbuatan yang dilarang dan diancam dengan suatu hukuman. ${ }^{25}$

Sedangkan Tindak pidana formal adalah tindak pidana yang dirumuskan dengan melarang melakukan tingkah laku tertentu, artinya dalam rumusan itu secara tegas disebutnya wujud perbuatan tertentu yang terlarang.

\footnotetext{
${ }^{25}$ Prasetyo Teguh,2012, Hukum Pidana, cet. III (Jakarta:Rajawali press,, hlm 167
} 
Tindak pidana formal, kriterianya ialah pada perbuatan yang dilarang tersebut. Apabila perbuatan terlarang selesai dilakukan, maka selesai pulalah tindak pidana, tanpa melihat atau bergantung pada akibat apa dari perbuatan itu. ${ }^{26}$

Delik Materiil adalah delik yang telah di anggap selesai dengan ditimbulkannya akibat yang dilarang dan di ancam dengan hukuman oleh undang-undang. Tindak pidana materiil adalah tindak pidana yang di rumuskan dengan melarang menimbulkan akibat tertentu disebut akibat terlarang. Titik beratnya larangan pada menimbulkan akibat terlarang. ${ }^{27}$

Contohnya adalah pembunuhan.

Terjadinya suatu pembunuhan tidak bergantung pada selesainya wujud perbuatan, tetapi apakah dari wujud perbuatan tersebut telah menimbukjan akibat berupa matinya seseorang atau tidak. Walaupun pada kenyataannya seseorang telah menghujam pisau kepada perut seseorang tetapi orang itu tidak mati, maka hal demikian belum dikatakan telah terjadi pembunuhan. ${ }^{28}$

Terwujudnya tindak pidana materiil secara sempurna adalah apabila akibat terlarang telah timbul dari tingkah laku. Dalam hal terwujudnya tindak pidana materiil secara sempurna di perlukan 3 syarat esensial, yaitu :

${ }^{26}$ Chazawi Adami 2005, Pelajaran Hukum Pidana 2, Cet II (Jakarta: PT Raja Grafindo Persada, hlm 213

${ }^{27}$ Idem, hlm 213-214

${ }^{28}$ Mahrus Ali, dasar - Dasar Hukum Pidana, Cet II (Jakarta: Sinar Grafika, 2012), hlm 105 
1. Terwujudnya tingkah laku

2. Terwujudnya akibat ( akibat konstutif atau constutief gevlog) dan

3. Adanya hubungan kausal (causaal verband) Antara wujud tingkah lau dengan akibat konstitutif ${ }^{29}$

Contoh kasus :

Seorang bapak yang mengidap penyakit jantung mengendarai sepeda motor hendak menyeberang mengambil jalur yang lain dengan berbelok ke kanan tanpa memperhatikan kendaraan dari arah belakang dan ketika itu ada mobil yang melaju dari arah belakang. Menghadapi kenyataan seperti itu si pengendara mobil menginjak rem sekuat tenaga sehingga mengeluarkan suara gesekan ban di jalan yang keras, yang menyebabkan bapak tadi terkejut. Walaupun mobil tidak sampai menabrak sepeda motor, namun tiba - tiba didepan mobil yang telah berhenti dan masih duduk diatas sadel sepeda motornya, bapak Itu rubuh dan jatuh pingsan. Kemudian, segera dilarikan kerumah sakit. Dirumah sakit ia tidak segera mendapatkan pertolongan, setengah jam kemudian meninggal dunia. ${ }^{30}$

Peristiwa tersebut merupakan satu contoh yang sulit dalam praktik hukum untuk menentukan ada tidaknya causal verband Antara wujud perbuatan ( pada contoh tersebut : mengemudikan kendaraan dengan tiba-tiba menginjak rem) dengan akibat yang timbul yakni kematian bapak tadi. Apakah yang menjadi penyebab kematian bapak

\footnotetext{
${ }^{29}$ Chazawi Adami, Op,Cit, hlm 214 ${ }^{30} \mathrm{lbid}$.
} 
ini? Pada peristiwa tersebut, terdapat beberapa faktor yang berpengaruh sehingga pada ujungnya menimbulkan kematian.

Rangkaian faktor itu ialah :

1. Korban berbelok kanan dan menyebrang dengan tiba-tiba

2. Pengemudi mobil dengan sekuat tenaga menginjak rem

3. Adanya bunyi keras dari gesekan ban dengan aspal; menyebabkan

4. Korban terkejut; menyebabkan

5. Kambuhnya penyakit jantung korban

6. Tidak segera mendapat pertolongan medis ${ }^{31}$

Dalam penentuan pertanggung jawaban pidana, mencari dan menetapkan factor yang menyebabkan kematian, ajaran kausalitas menjadi penting. Ajaran kausalitas akan menunjukkan perbuatan mana sebenarnya yang harus di anggap sebagai penyebab dari timbulnya akibat. ${ }^{32}$

\section{B.MACAM - MACAM TEORI KAUSALITAS}

Ada beberapa ajaran kausalitas yang dapat dikelompokkan ke dalam 3 teori yang besar. Yaitu:

1)Teori conditio sine qua non

\footnotetext{
${ }^{31} \mathrm{lbid}$

${ }^{32}$ Mahrus Ali, Op.cit,hlm 106
} 
2) Teori - teori yang mengindividualisasi (individualserede theorien), dan

3) Teori - teori yang menggeneralisasi (generaliserende theorien)

\section{Teori Conditio sine qua non}

Teori ini pertama kali dicetuskan pada tahun 1873 oleh Von Buri seorang ahli hukum Jerman. Teori ini juga dinamakan teori ekuivalensi dan bedingungtheorie. Disebut teori ekuivalensi, karena menurut pendiriannya, tiap-tiap syarat adalah sama nilainya. Semua faktor sama pentingnya terhadap timbulnya suatu akibat. Di sebut bedigungtheorie, karena baginya tidak ada perbedaan Antara syarat (bedingung) dengan musabab atau penyebab 33

Dalam perspektif hukum pidana, teori ini mengandung kelemahan yang sangat mendasar, karena dalil yang dibangun itu , hubungan kausalitas terbentang tanpa akhir, mengingat tiap - tiap sebab hakekatnya merupakan akibat dari sebab yang terjadi sebelumnya. ${ }^{34}$

\section{Contoh :}

B ditikam oleh A sampai mati. Yang merupakan sebab bukan hanya ditikam $A$, tetapi juga penjualan pisauitu kepada $A$ dan penjualan

\footnotetext{
${ }^{33}$ C.S.T Kansil, Latihan Ujian Hukum Pidana,Cet. III (Jakarta: Sinar Grafika,2007), hlm 119.

${ }^{34}$ Mahrus Ali,Op. Cit, hlm 107.
} 
pisau itu tidak ada, apabila tidak ada pembuatan pisau. Jadi pembuatan pisau itu juga "sebab" dan begitu seterusnya.

Berhubungan dengan keberatan itu, maka ada teori - teori lain yang hendak membatasi teori tersebut. Mengambil dari sekian faktor yang menimbulkan akibat itu beberapa faktor yang kuat (dominan), sedangkan faktor - faktor lain dipisahkan sebagai faktor - faktor yang irrelevant (yang tidak perlu/penting).

\section{Teori yang mengindividualisasi}

Teori yang mengindividualisasi ialah teori yang dalam usahanya mencari faktor penyebab timbulnya dari suatu akibat dengan hanya melihat pada faktor yang ada atau terdapat setelah perbuatan di lakukan, dengan kata lain setelah peristiwa itu beserta akibatnya benar benar terjadi secara kongkret (post factum). Menurut teori ini, setelah peristiwa terjadi, maka diantara sekian rangkaian faktor yang terkait dalam peristiwa itu, tidak semuanya merupakan faktor penyebab. Faktor penyebab itu adalah hanya berupa faktor yang paling berperan atau dominan atau mempunyai andil yang paling kuat terhadap timbulnya suatu aibat, sedangkan faktor lain adalah dinilai sebagai faktor syarat saja dan bukan faktor penyebab. Pendukung teori yang mengindividualisasi ini antara lain birkmenyer dan kari binding.

\section{Teori yang menggeneralisasi}

Teori yang menggeneralisasi adalah teori yang dalam mencari sebab (causa) dari rangkaian faktor yang berpengaruh atau berhubungan dengan timbulnya akibat adalah dengan melihat dan 
menilai pada faktor mana yang secara wajar dan menurut akal serta pengalaman pada umumnya dapat menimbulkan suatu akibat.

Jadi, mencari factor penyebab dan menilainya tidak berdasarkan pada faktor setelah peristiwa terjadi beserta akibatnya, tetapi pada pengalaman pada umumnya menurut akal dan kewajaran manusia atau disebut secara abstracto, tidak secara inconcreto. Dalam teori ini dicari sebab yang adequate untuk timbulnya akibat yang bersangkutan. Oleh karena itu teori ini disebut dengan teori adequate. Contoh - contoh tentang ada atau tidaknya hubungan sebab akibat yang adequate :

1. Suatu pukulan yang ditujukan ke hidung, dapat mengakibatkan hidung keluar darah. Akan tetapi apabila orang yang dipukul itu menjadi buta itu bukan akibat yang adequate. Ini suatu akibat yang abnormal, yang tidak biasa.

2. Sopir truk terpaksa mengerem mendadak, oleh karena ada pengendara sepeda motor hendak menyeberang jalan yang membelok diarah kanan, sedang ini tidak disangka oleh pengendara mobil. Pengendara mobil ini mendapat penyakit trauma karena menekan urat. Dan ini pun dapat dikatakan bahwa perbuatan pengendara sepeda itu tidak merupakan penyebab yang adequate untuk timbulnya penyekit trauma tersebut.

3. Seorang petani membakar tumpukan rumput kering, dimana secara kebetulan bersembunyi/tidur penjahat hingga ikut mati terbakar. Adakah penyebab yang adequqte ? jawabnya tergantung dari keadaan . jika biasanya menurut pengalaman sehari - hari , tidak timbul akibat semacam itu maka perbuatan 
petani itu bukanlah sebab. Akan tetapi apabila di daerah itu merupakan kebiasaan orang untuk bersembunyi atau menginap dalam tumpukan rumput, maka perbuatan petani itu benar - benar mempunyai kadar untuk matinya seseorang.

4.

\section{KAUSALITAS DALAM HAL TIDAK BERBUAT}

Persoalan ini timbul dalam belik - delik omisasi dan dalam delik comisionis per ommsionem commissa (delik omissi yang sesungguhnya). Jenis kedua ini delik comissi yang di lakukan dengan "tidak berbuat". Pada delik omissi persoalannya mudah, karena delik omissi itu adalah delik formil, sehingga tidak ada persoalan tentang kausalitas.

Yang ada persoalan ialah pada delik commisionis per omission commissa. Pada delik ini ada pelanggaran larangan dengan "tidak berbuat". Dalam persoalan ini ada beberapa pendirian :

1. Tidak mungkin orang yang tidak berbuat bisa menimbulkan akibat. Pendirian ini di dasarkan kepada dalil ilmu pengetahuan alam yang berbunyi bahwa dari keadaan negative tidak mungkin timbul keadaan positif. Pendirian ini tidak bisa di terima. Karena dalil pengetahuan alam tidak tepat untuk dipakai dalam ilmu pengetahuan rokhani ( seperti hukum pidana ini).

2. Yang disebut sebab ialah perbuatan yang positif yang di lakukan oleh si pembuat pada saat akibat itu timbul. Misal : 
Dalam hal seorang ibu membunuh anaknya dengan tidak memberi susu, yang disebut sebab ialah "Sesuatu yang di lakukan ibu itu pada saat ia tidak memberi itu susu, missal pergi ke toko. Teori inipun tidak dapat di terima. Karena kepergian ibu itu tidak bisa dianggap ada perhubungan dengan akibat itu

3. Yang di sebut sebab ialah perbuatan yang mendahului akibat yang timbul. Teori ini disebut "Teori berbuat yang sebelumnya", misal seseoramg penjaga wesel yang menyebabkan kecelakaan kereta api karena tidak memindahkan wesel; menurut ajaran ini yang menjadikan sebab ialah apa yang di lakukan penjaga wesel. Teori inipun tidak memuaskan, sebab sulit dilihat hubungannya antara penerima jabatan dengan akibat yang timbul.

4. Seorang yang tidak berbuat dapat di katakana sebab dari suatu akibat, apabila ia mempunyai kewajiban hukum untuk berbuat. Kewajiban itu timbul dari hukum, tidak hanya yang nyata tertulis dalam suatu peraturan tetapi juga dari peraturan-peraturan yang tertulis, ialah norma-norma lain yang berlaku dalam masyarakat yang teratur. Di bawah ini di beri contoh-contoh apakah ada kewajiban berbuat atau tidak

1) Ada ana yang di bunuh; Orang tuanya mengetahui hal ini, tetapi tidak berbuat apa-apa. Apakah orang tua bertanggung jawab sebagai ikut berbuat dalam pembunuhan? Jawab (Hof Amsterdam 23 Oktober 1883): tidak, tetapi memang sikap semacam itu sangat tercela (laakbar) dan tidak patut. 
2) Seorang penjaga gudang membiarkan pencuri melakukan aksinya, ia dapat di pertanggung jawabkan, sebab sebagai penjaga ia berkewajiban untuk menjaga dan berbuat sesuatu.

Kesimpulan mengenai kausalitas dalam hal tidak berbuat; sekarang tidak ada persoalan lagi, bahwa tidak berbuat dapat menjadi sebab dari suatu aibat. "tidak berbuat" sebenarnya juga merupakan "perbuatan". Dalam delik commisionis per imissionem commissa (delik omissi yang tidak sesungguhnya) "tidak berbuat" itu bukannya "tidak berbuat sama sekali" akan tetapi "tidak berbuat sesuatu", yang di harapkan untuk diperbuat/dilakukan. Maka dengan pengertian ini hal "Tidak berbuat" pada hakekatnya sama dengan "berbuat sesuatu", dalam arti data menjadi syarat untuk terjadinya suatu akibat. Sedang menurut teori adequate, mengingat keadaan yang kongkrit, dapat juga mempunyai kadar untuk terjadinya akibat, jad juga dapat menjadi "sebab"

\section{SOAL - SOAL LATIHAN}

2. Jelakan tentang ajaran kausalitas

3. Sebutkan dan terangkan secara detail macam - macam teori kausalitas.

4. Jelaskan tentang kausalitas dalam hal tidak berbuat. 


\section{REFERENSI}

Chazawi Adami, 2005, Pelajaran Hukum Pidana bagian 2, Cet II Jakarta: PT Raja Grafindo Persada,

Kansil C.S.T , 2007 Latihan Ujian Hukum Pidana,Cet. III ,J akarta: Sinar Grafika,

Ali Mahrus , 2012, Dasar-Dasar Hukum Pidana, Cet II Jakarta: Sinar Grafika,

Teguh Prasetyo, Hukum Pidana, cet. III Jakarta:Rajawali press,2012, 


\section{DAFTAR PUSTAKA}

Adami Chazawi, Pelajaran Hukum Pidana 2, Cet II Jakarta: PT Raja Grafindo Persada,2005,

Andi Zaenal Abidin, Asas-asas Hukum Bagian Pertama, Alumni, Bandung, 1987.

Andi Hamzah, Asas-asas Hukum Pidana di Indonesia dan perkembangannya, sofmedia, Jakarta, 2012.

Bambang Waluyo, Pidana dan Pemidanaan, Sinar Grafika, Jakarta, 2008.

Bemmelen, Hukum Pidana I, Binacipta, Jakarta, 1984.

C.S.T Kansil, Latihan Ujian Hukum Pidana,Cet. IIIJakarta: Sinar Grafika,2007),

EY Kanter dan SR Sianturi, Asas-asas Hukum Pidana di Indonesia dan Penerapannya, Storia Grafika, 2002, Jakarta.

Ernest Utrecht, Hukum Pidana 1 Pustaka Tirta Mas, Surabaya, 1994.

Kitab Undang-Undang Hukum Pidana (KUHP)

Mahrus Ali, Dasar - Dasar Hukum Pidana, Cet II Jakarta: Sinar Grafika, 2012,

Masruchin Ruba'l, Buku Ajar Hukum Pidana,Media Nusa Creative, Malang, 2015 
Moeljatno, Asas-asas Hukum Pidana, Gajah Mada University Press, Yogyakarta, 1980.

Moeljatno, Azas-azas Hukum Pidana, Bina Aksara, Jakarta, 1983.

PAF Lamintang, Dasar-dasar Hukum Pidana Indonesia, Cipta Dutya Bakti, Bandung, 1997.

Sudarto, Hukum Pidana Jilid 1A, Bagian Penerbitan dan Biro Perpustakaan dan Penerbitan, Fakultas Hukum dan Pengetahuan Masyarakat Universitas Brawijaya, Malang, 1974.

SR Sianturi, Asas-asas Hukum Pidana di Indonesia dan Penerapannya, Alumni AHAEM-PETAHAEM, Jakarta, 1989.

Simons, Kitab Pelajaran Hukum Pidana (Leerboek Van Het Nederlanches Strafrecht), terjemahan dari PAF Lamintang, Pionir Jaya, Bandung, 1992.

Teguh Prasetyo, Hukum Pidana, cet. III Jakarta:Rajawali press,2012,

Undang-Undang Nomor 8 Tahun 1981 tentang Hukum Acara Pidana (Dalam Ketentuan Penutup disebut Kitab Undang-Undang Hukum Acara Pidana (KUHAP)).

Wirjono Prodjodikoro, Asas-asas Hukum Pidana Indonesia, PT. Eresko, Bandung, 1986. 


\section{BIODATA PENULIS}

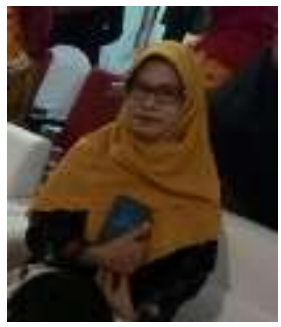

Emy Rosnawati, SH MH dilahirkan di Kediri, 10 Juli 1969. Pada tahun 1992, penulis mendapatkan gelar Sarjana Hukum dari Universitas Brawijaya Malang. Penulis mendapatkan gelar Magister Hukum di Universitas Surabaya Tahun 2012. Penulis sebagai Dosen di prodi Ilmu Hukum Universitas Muhammdiyah Sidoarjo. Selain pendidikan dan pengajaran penulis juga aktif dalam kegiatan penelitian dan pengabdian kepada masyarakat baik didanai oleh Ristekdikti maupun dana mandiri. Penulis aktif mengikuti berbagai kegiatan akademik, pengurus Asosiasi Pengajar Hukum Pidana Perguruan Tinggi Muhammadiyah (APHPidana PTM), Anggota Asosiasi Laboratorium Hukum Indonesia. Anggota Majelis Hukum dan HAM Pimpinan Daerah Aisiyah Sidoarjo.

Abdul Fatah, S.H., M.H. dilahirkan di Lamongan, 07 Oktober 1984. Penulis menyelesaikan pendidikan tingginya Program Sarjana di Universitas Jember pada tahun 2008 dan Program Magister di Universitas Airlangga Surabaya pada tahun 2013. Penulis menjadi Dosen Tetap di Prodi IImu Hukum Universitas Muhammadiyah Sidoarjo dan menjadi pengurus Asosiasi Pengajar Hukum Pidana Perguruan Tinggi

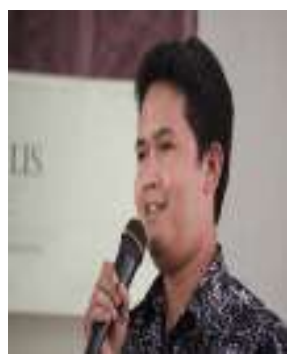
Muhammadiyah (APHPidana PTM) dan sebagai Wakil Sekretaris Majelis Hukum dan HAM Pimpinan Wilayah Muhammadiyah Jawa Timur. Penulis juga aktif dalam konferensi hukum dan filsafat hukum baik nasional maupun Internasional. Konferensi internasional terakhir yang diikuti adalah Asia Pro Bono Conference, dan juga rutin sebagai pengajar Pendidikan Khusus Profesi Advokat (PKPA). 